Report No. BMI-1242

UC-10 Chemistry - Separation

Processes for Plutonium and

Uranium

(TID-4500, 13th Ed., Suppl.)

Contract No. W-7405-eng-92

EVALUATION OF CONTAINER MATERIALS FOR ZIRCEX AND DAREX NUCLEAR-FUEL-RECOVERY PROCESSES

by

Paul D. Miller

Charles L. Peterson

Earl L. White

Frederick W. Fink

December 11, 1957

BATTELLE MEMORIAL INSTITUTE

$505 \mathrm{King}$ Avenue

Columbus 1, Ohio 


\section{DISCLAIMER}

This report was prepared as an account of work sponsored by an agency of the United States Government. Neither the United States Government nor any agency Thereof, nor any of their employees, makes any warranty, express or implied, or assumes any legal liability or responsibility for the accuracy, completeness, or usefulness of any information, apparatus, product, or process disclosed, or represents that its use would not infringe privately owned rights. Reference herein to any specific commercial product, process, or service by trade name, trademark, manufacturer, or otherwise does not necessarily constitute or imply its endorsement, recommendation, or favoring by the United States Government or any agency thereof. The views and opinions of authors expressed herein do not necessarily state or reflect those of the United States Government or any agency thereof. 


\section{DISCLAIMER}

Portions of this document may be illegible in electronic image products. Images are produced from the best available original document. 
TABLE OF CONTENTS

Page

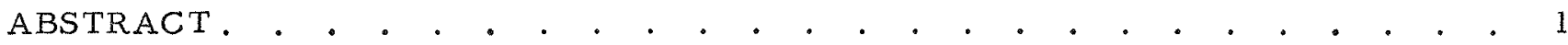

INTRODUCTION • . . . . . . . . . . . . . . . . . . . . . . 1

THE ZIRCEX PROCESSES . . • . . • . • . . . . . . . . . . . . 2

Gas-Phase Hydrochlorination . . . . . . . . . . . . . . . . . 2

The Dissolution Step . . . . . . . . . . . . . . . . . 2

Cyclic Tests for Both Hydrochlorination and Dissolution Steps. . . . 13

Liquid-Phase Hydrochlorination . . . . . . . . . . . . . . 25

THE DAREX PROCESS . . . . . . . . . . . . . . . . . . . . 30

Elimination-Type Tests . . . . . . . . . . . . . . . . . . 30

Corrosion Tests in Operating Dissolvers . . . . . . . . . . . . . 34

Miscellaneous Tests for Galvanic Attack . . . . . . . . . . . . 36

CHLORIDE-STRIPPER STUDIES . . . . . . . . . . . . . . . . . 37

PUREX ACID-EXTRACTION SYSTEM . . . . . . . . . . . . . . . . . 40

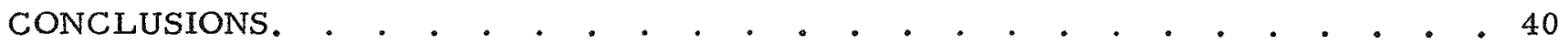

Zircex Technology • . . . . . . . . . . . . . . . . 40

Darex Technology. . . . . . . . . . . . . . . . . . . . . 42

REFERENCE . . . . . . . . . . . . . . . . . . . . . . . . . . 42 


\title{
EVALUATION OF CONTAINER MATERIALS FOR ZIRCEX AND DAREX NUCLEAR-FUEL-RECOVERY PROCESSES
}

\author{
Paul D. Miller, Charles L. Peterson, Earl L. White, \\ and Frederick W. Fink
}

\begin{abstract}
The selection of a suitable material for the processing equipment is most important in fuel-recovery processes. The problem arises because of the aggressive nature of the reagents that must be used for disintegrating or dissolving some spent fuel elements. In this investigation, corrosion tests were made under conditions simulating those that may occur in several proposed processes in order that candidate materials of construction could be evaluated.

No material has been found which would allow both the hydrochlorination and dissolution steps of the vapor-phase Zircex process to be carried out in a single vessel. For a two-vessel process, several materials, such as Inconel, Haynes 25, Type S-816 alloy, Illium $R$, and the Hastelloys $B$ and $C$, appear promising for construction of a hydrochlorinator; the dry residue would then be transferred to another vessel, perhaps of titanium or tantalum, for dissolution.
\end{abstract}

In the alternate liquid-phase Zircex process, preliminary tests have given promising results with nickel and nickel-chromium alloys. However, the only metals studied, which withstand the corrosive boiling $\mathrm{AlCl}_{3} \cdot \mathrm{NH}_{4} \mathrm{Cl}$ plus gaseous $\mathrm{HCl}$ environment with but negligible weight losses have been platinum, gold, tungsten, and molybdenum.

A variety of laboratory studies have shown that titanium will apparently withstand any condition likely to occur in the critical areas of the Darex process, including the dissolver and chloride-stripping column. It will undergo a severe attack in $H C l$ vapor, but this is easily prevented by the presence of a small amount of nitric acid vapor or oxides of nitrogen. Tantalum is another promising material disclosed by these tests, but its use in the dissolver seems negated because embrittlement was detected under certain conditions.

No signs of cracking or other attack have been observed on Type 347 stainless steel specimens exposed at room temperature with various levels of stress for over 6 months to Purex-type acid extraction systems containing chlorides far in excess of the concentrations expected during operation of either the Zircex or Darex head-end processes.

\section{INTRODUCTION}

Various processes are now under study at several AEC sites for the separation of the fissionable materials from the fission products in spent power-reactor fuel elements. Two of these processes, the Zircex and the Darex, may be used as head-end methods for making uranium available in a nitrate solution suitable for solvent extraction by conventional means. The Zircex process will handle fuel elements containing zirconium as a cladding or diluent, while elements containing stainless steel would be rendered soluble in the Darex process by dilute aqua regia, from which the name for the process is derived. These and other processes for the recovery of spent fuel elements are being 
developed by the Chemical Technology Division of the Oak Ridge National Laboratory and have been described in the literature. (1) The corrosion evaluation of materials of construction for these processes is being carried out by Battelle Memorial Institute as part of a program of assistance to the Chemical Technology Division.

\section{THE ZIRCEX PROCESSES}

Use is made of the volatility of zirconium tetrachloride to separate uranium from zirconium alloy or cladding in the Zircex processes. In one proposed operation, the hydrochlorination could be effected by means of $\mathrm{HCl}$ gas in a gas-phase type of reaction conducted at 300 to $600 \mathrm{C}$. The volatile $\mathrm{ZrCl}_{4}$ would be removed and the $\mathrm{UCl}_{3}$ dissolved in water or nitric acid. The resulting solution, after chloride stripping and proper adjustment, would be handled by the usual methods for solvent extraction in order that the uranium values might be reclaimed.

An alternate liquid-phase hydrochlorination process has been proposed. Elements would be dissolved and hydrochlorinated in a refluxing low-melting coordination compound such as $\mathrm{AlCl}_{3} \cdot \mathrm{NH}_{4} \mathrm{Cl}$, using $\mathrm{HCl}$ gas at about $400 \mathrm{C}$. The volatile $\mathrm{ZrCl}_{4}$ would sublime. The melt would then be distilled to recover the aluminum and ammonium chlorides and the residual uranium and other nonvolatile metal chlorides would be dissolved in water and nitric acid in preparation for solvent extraction.

\section{Gas-Phase Hydrochlorination}

The Dissolution Step

From a technical and economic viewpoint, it would be preferable if the dissolution of the metallic or metal chloride residue, following the gas-phase hydrochlorination, could be carried out in the same reaction vessel. Accordingly, fairly extensive investigations have been undertaken to evaluate materials for the construction of such a vessel. With the requirements of the hydrochlorination step in mind, 15 likely materials were chosen and screened in preliminary tests under conditions approximating those of the dissolution step. Boiling solutions, whose compositions simulated those that could occur at various stages during the dissolution, were used. The solution compositions can be found listed on Figures 1,2 , and 3.

The approximate composition of the materials above which were screened and others which were considered in the program are given in Table 1. Specimens of each candidate were exposed at the boiling liquid, interface, and vapor positions in units consisting of Erlenmeyer flasks topped by water-cooled Allihn condensers operated with continuous refluxing. The specimens were usually removed at weekly intervals, washed and scrubbed free of any easily removable corrosion products, and weighed. The loss in weight was then converted to a corrosion rate, expressed as average penetration in mils

per month. Visual examination also was made at the time of weighing. Usually the acid solution was renewed before replacing the specimens for another exposure period.

(1) References at end. 


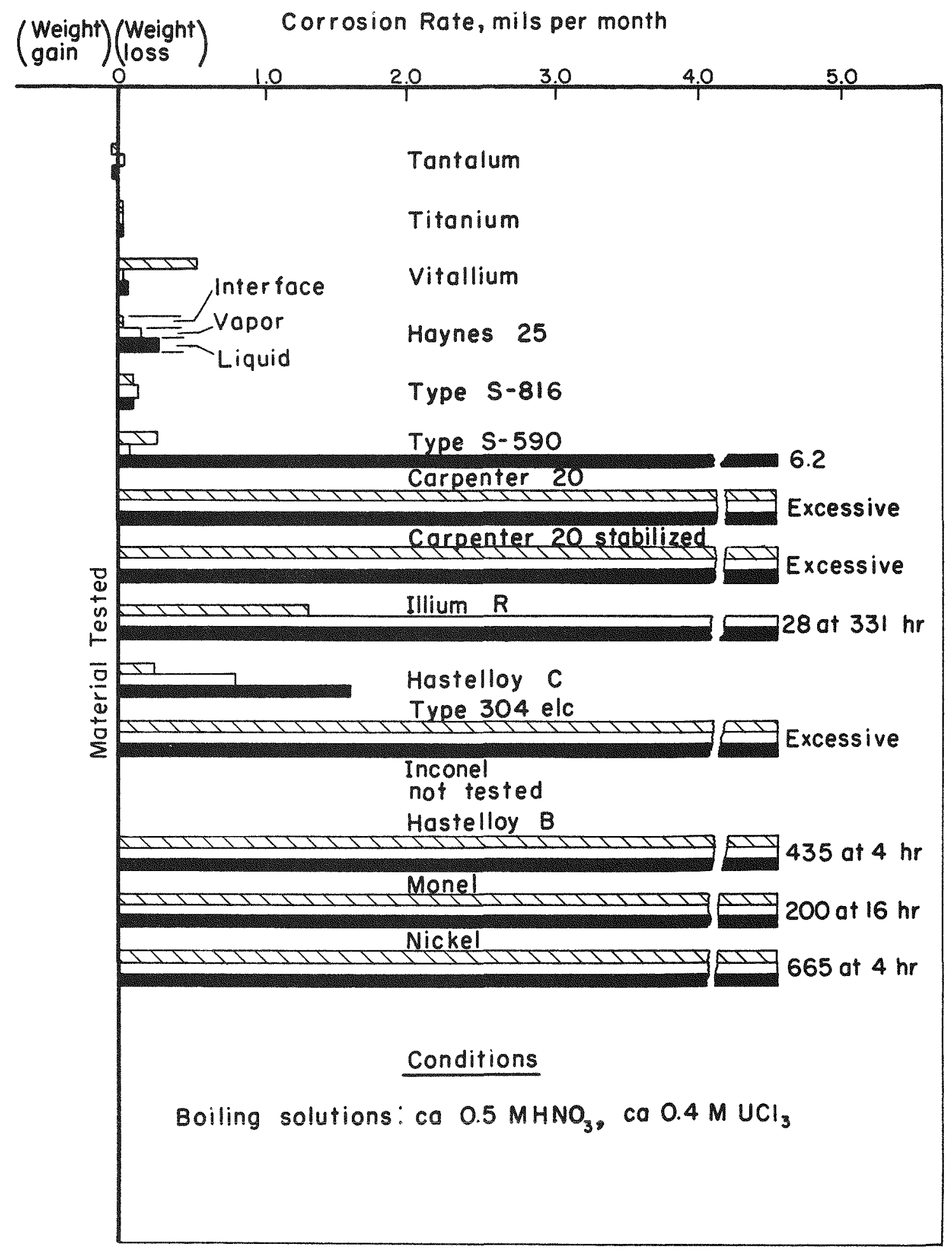

A-22321

FIGURE 1. CORROSION RESULTS IN 0.5 M ZIRCEX SOLUTIONS (BOILING) 4 weeks of exposure unless noted otherwise. 


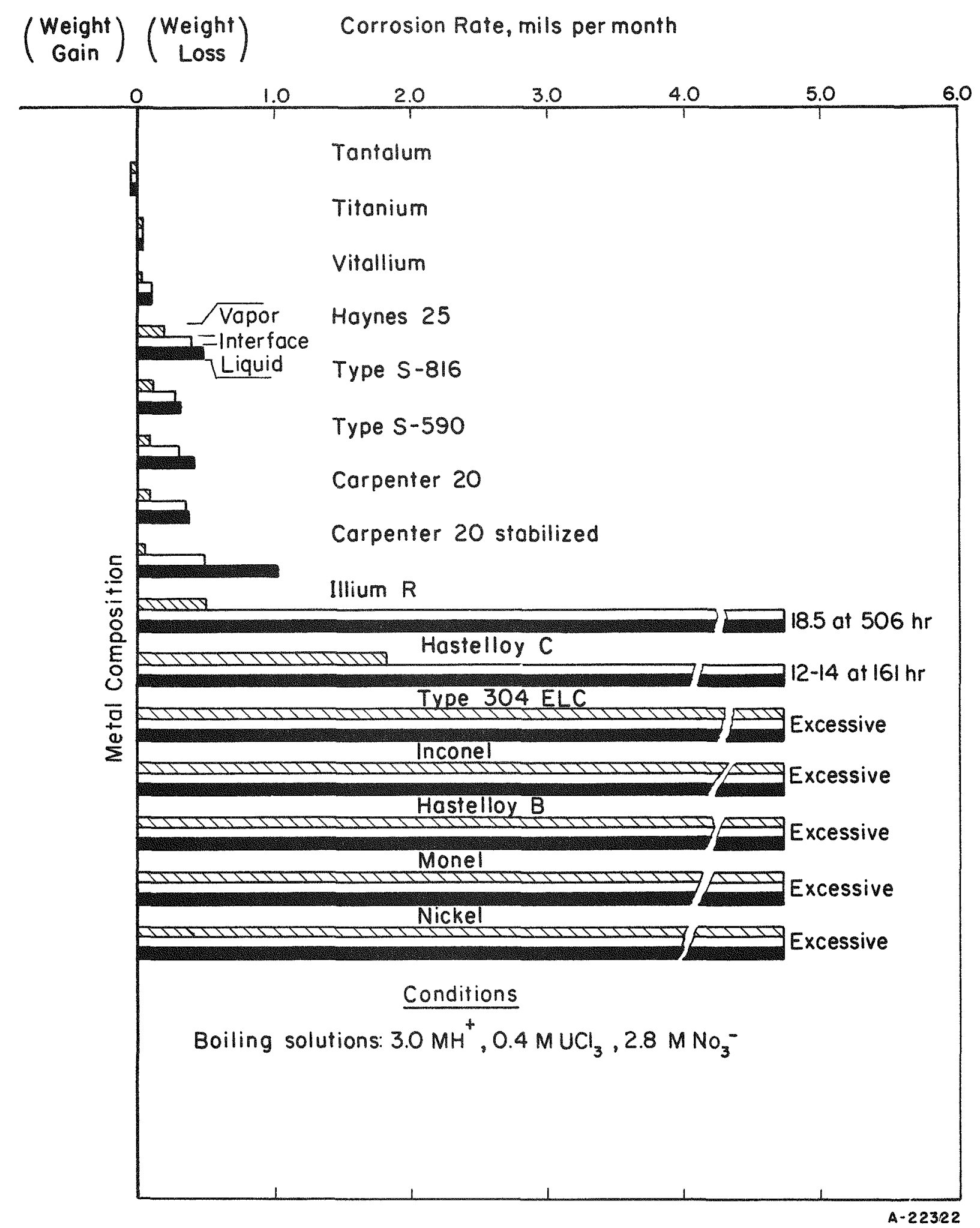

FIGURE 2. CORROSION RESULTS IN 3 M ZIRCEX SOLUTIONS (BOILING)

4 weeks of exposure unless noted otherwise. 


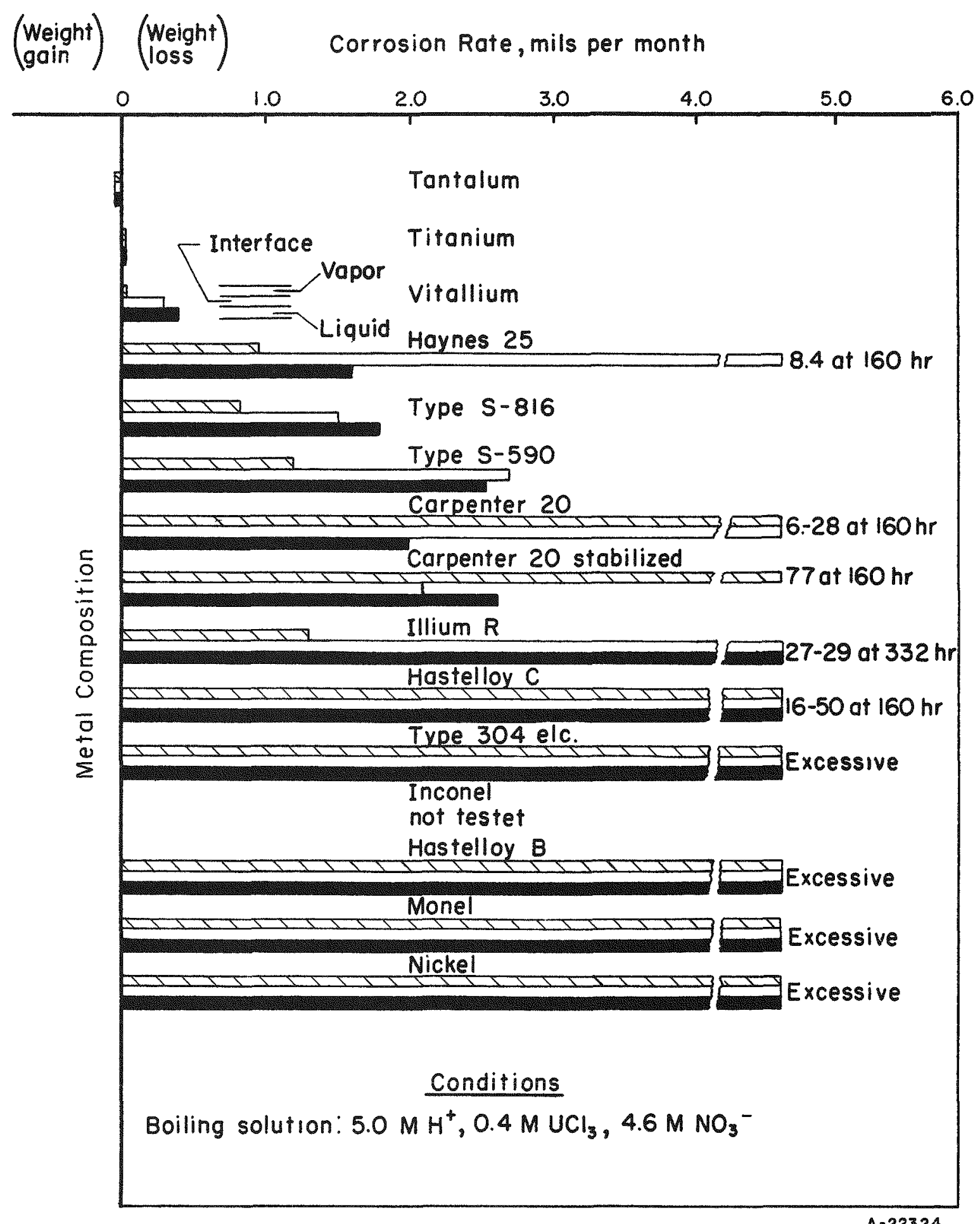

FIGURE 3. CORROSION RESULTS IN 5 M ZIRCEX SOLUTIONS (BOILING) 4 weeks of exposure unless noted otherwise. 
TABLE 1. COMPOSITION OF CANDIDATES CONSIDERED FOR MATERIALS OF CONSTRUCTION

\begin{tabular}{|c|c|c|c|c|c|c|c|c|c|c|c|c|c|}
\hline \multirow[b]{2}{*}{ Metal } & \multirow[b]{2}{*}{ Symbol } & \multicolumn{12}{|c|}{ Nominal Composition, w/o } \\
\hline & & Co & $\mathrm{Cr}$ & $\mathrm{Ni}$ & $\mathrm{Fe}$ & Mn & Mo & $\mathrm{Cu}$ & $\mathrm{Si}$ & $W$ & $\mathrm{C}$ & $\mathrm{Nb}$ & B \\
\hline Tantalum & TA & $-\infty$ & - & $-\infty$ & -- & - & - & -- & - & - & - & - & -- \\
\hline Titanium & $\mathrm{TI}$ & $\cdots$ & $\cdots$ & - & $\cdots$ & - & - & -. & - & - & -- & -- & - \\
\hline Vitallium & VIT & 62.2 & 27.4 & 2.8 & 0.7 & 0.66 & 5.5 & -- & 0.53 & -- & 0.22 & -. & -- \\
\hline Haynes 21 & & 62.0 & 28.0 & 2.5 & $2.0 \max$ & - & 5.2 & - & -- & -- & 0.30 & -- & -- \\
\hline Haynes 23 & & 64.6 & 26.0 & $1.5 \max$ & $2.0 \max$ & -- & -. & -- & - & 5.5 & 0.40 & - & -- \\
\hline Haynes 25 & $\mathrm{H} 25$ & 50.4 & 20.0 & 10.0 & $2.0 \max$ & 1.5 & $\ldots$ & -- & $1.0 \max$ & 15.0 & $0.15 \max$ & -. & $\ldots$ \\
\hline Haynes 30 & & 50.6 & 26.0 & 15.0 & $2.0 \max$ & -- & 6.0 & -- & -- & $\cdots$ & 0.40 & - & $\cdots$ \\
\hline Haynes 36 & & 52.8 & 18.5 & 10.0 & $2.0 \max$ & 1.3 & -. & -- & 0.50 & 14.5 & 0.40 & $-\infty$ & 0.03 \\
\hline Type S-816 & S816 & 44.7 & 19.0 & 20.0 & 3.0 & 0.6 & 4.0 & -- & 0.3 & 4.0 & 0.40 & 4.0 & - \\
\hline Type $\mathbf{-}-590$ & S590 & 20.0 & 19.7 & 20.0 & 26.0 & 2.0 & 3.7 & -. & 1. $0 \max$ & 3.75 & 0.45 & 3.75 & - \\
\hline Carpenter 20 & $\mathrm{C} 20$ & $\cdots$ & 20.0 & 29.0 & 44.2 & 0.75 & 2.0 & 3.0 & 1.0 & -. & 0.07 & $\cdots$ & -. \\
\hline Carpenter 20 stabilized & $\mathrm{C} 20 \mathrm{~S}$ & - & 20.0 & 29.0 & 43.6 & 0.75 & 2.0 & 3.0 & 1.0 & -. & - & 0.7 & -- \\
\hline Type 304 stainless & 304 & -- & 19.0 & 9.5 & 68.4 & 2.0 & $\cdots$ & -- & 1.0 & -- & 0.08 & $-\infty$ & -- \\
\hline Hastelloy $\mathrm{X}$ & & -- & 22.0 & 45.0 & 23.9 & - & 9.0 & -- & -. & -- & $0.15 \max$ & -- & -- \\
\hline Hastelloy $F$ & & 2.5 & 22.0 & 45.0 & 21.0 & 1.55 & 6.0 & -. & 1.0 & 1.0 & -- & -- & -. \\
\hline Hastelloy C & $\mathrm{HAC}$ & $2.5 \max$ & 15.5 & 54.6 & 5.5 & 1.0 & 16.0 & $\cdots$ & 1.0 & 3.8 & 0.08 & -- & -. \\
\hline Illium $R$ & ILR & -- & 22.0 & 63.8 & 2.5 & 1.0 & 6.5 & 4.0 & -. & -- & 0.20 & -- & - \\
\hline Inconel & & -- & 15.5 & 76.2 & 7.5 & 0.25 & -- & 0.2 & 0.25 & -. & 0.08 & -- & -- \\
\hline "A" Nickel & NIA & - & $-\infty$ & $99 .+$ & -- & - & - & -- & - & -- & -- & -- & -- \\
\hline Monel & & 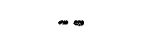 & $m$ & 67.2 & 1.5 & 1.0 & - & 30.0 & 0.1 & $\cdots$ & 0.15 & - & -- \\
\hline Nichrome $\mathrm{V}$ & & $\cdots$ & 19.0 & 75.8 & $1.0 \mathrm{max}$ & $2.5 \max$ & & - & 1.5 & - & $0.25 \max$ & -- & - \\
\hline Hastelloy B & & - & $\cdots$ & 65.0 & 5.0 & 1.00 & 28.0 & $\cdots$ & 1.0 & -- & -- & $\cdots$ & -. \\
\hline Hastelloy W & & - & 6.0 & 61.5 & 5.5 & 1.0 & 25.0 & -- & 1.0 & $\cdots$ & -- & $\cdots$ & -- \\
\hline
\end{tabular}


A limiting value of 3 mils per month was arbitrarily chosen for the maximum allowable corrosion rate before the testing of a material was discontinued. On this basis, over half of the candidate materials were eliminated from further consideration. The corrosion rates for those materials showing the best resistance to corrosion are summarized in Table 2. The extent of the corrosion, measured following 4 weeks of exposure, is shown in Figures 1, 2, and 3, while the appearance of the specimens at the conclusion of the tests, along with the final corrosion rates, can be found in Figures 4 , 5 , and 6. The symbols used for column headings in Figures 4, 5, and 6 refer to the designations shown in Table 1 .

The candidate materials were also evaluated in boiling solutions of $15 \mathrm{M} \mathrm{HNO}_{3}$, $0.4 \mathrm{M} \mathrm{UO}_{2}\left(\mathrm{NO}_{3}\right)_{2}$ through which $\mathrm{HCl}$ gas was bubbled. Since the flow of HCl tended to deplete these solutions in $\mathrm{HNO}_{3}$, the materials were exposed in a gradually changing environment. For example, at the $\mathrm{HCl}$ flow rate used, nitrate ion was completely expelled from the solution after several weeks and the chloride concentration increased until the approximate composition of azeotropic $\mathrm{HCl}$ was reached.

Some representative results from this series of elimination tests are given in Table 3. Only corrosion data prior to depletion of nitrates in the bath are recorded. Specimens of tantalum showed small weight gains, indicating negligible corrosion. Carpenter 20 showed good resistance in these elimination tests but performed poorly during subsequent cyclic tests when cycled into somewhat similar solutions. Carpenter 20 stabilized, not shown, had slightly higher corrosion rates. Specimens of as-cast Haynes 21 were soon disqualified from the test, but specimens cut from pieces of Haynes 21 , rolled at Battelle, showed reasonable corrosion rates even after 8 weeks of exposure.

Specimens of $75 \mathrm{~A}$ titanium, the titanium- $6 \mathrm{w} / \mathrm{o}$ aluminum-4 w/o vanadium alloy, and those of RC-55 titanium ran for several weeks with only negligible weight losses. Nitrate ion was still detectable in these solutions at the end of the exposure periods. However, in other tests with titanium and in a test with Type S-816 specimens, a severe attack leading to a rapid failure of the specimens occurred suddenly during the fourth week of exposure. Only low corrosion rates had been measured up to the time of failure. Analyses of the solutions remaining from these tests showed that the nitrate ion had been completely expelled. It has never been possible to detect nitrates in any of the solutions remaining after the severe attack of titanium. The color of these solutions indicates that there may be a correlation between the oxidation potential necessary for the passivation of titanium and that required for the oxidation of uranium to the hexavalent state. However, this has not been substantiated.

Thus, it has been concluded that any contemplated utilization of titanium must, of necessity, provide adequate oxidizing conditions to maintain the metal in a passive state; otherwise, catastrophic failure can occur. These conclusions have been further confirmed by tests in simulated Zircex and Darex chloride-stripper solutions which will be described later.

Experiments of a preliminary nature have indicated that probably a fairly small nitrate concentration (perhaps a fraction of a mole per liter) is all that is necessary to provide adequate oxidizing conditions, but, so far, the nitrate concentration necessary has not been accurately defined. 
TABLE 2. MATERIALS PASSING THE ZIRCEX ELIMINATION TESTS

\begin{tabular}{ll}
\hline Zircex Test & \multicolumn{1}{c}{$\begin{array}{c}\text { Material (Arranged in Order of } \\
\text { Decreasing Resistance) }\end{array}$} \\
\hline \multirow{2}{*}{$0.5 \mathrm{M}$} & Titanium \\
& Tantalum \\
& Type S-816 \\
& Haynes 25 \\
& Vitallium \\
& Hastelloy C \\
$3 \mathrm{M}$ & Tantalum \\
& Titanium \\
& Vitallium \\
& Type S-816 \\
& Carpenter 20 \\
& Type S-590 \\
& Haynes 25 \\
& Carpenter 20 stabilized \\
& Tantalum \\
& Titanium \\
& Vitallium \\
& Type S-816 \\
& Type S-590 \\
\hline
\end{tabular}




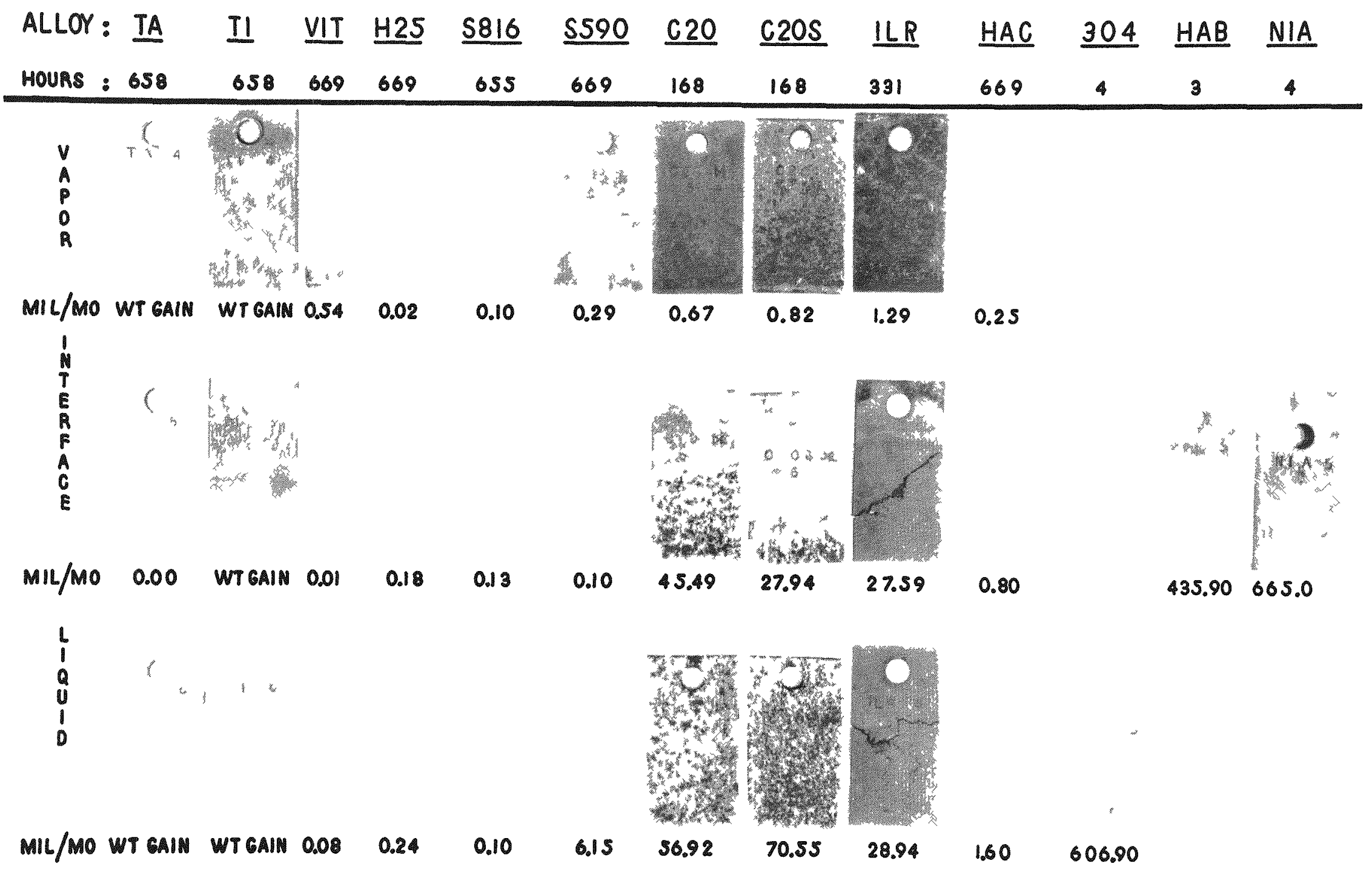

FIGURE 4. SPECIMENS FOLLOWING EXPOSURE IN $0.5 \mathrm{M}$ ZIRCEX SOLUTIONS (BOILING) 


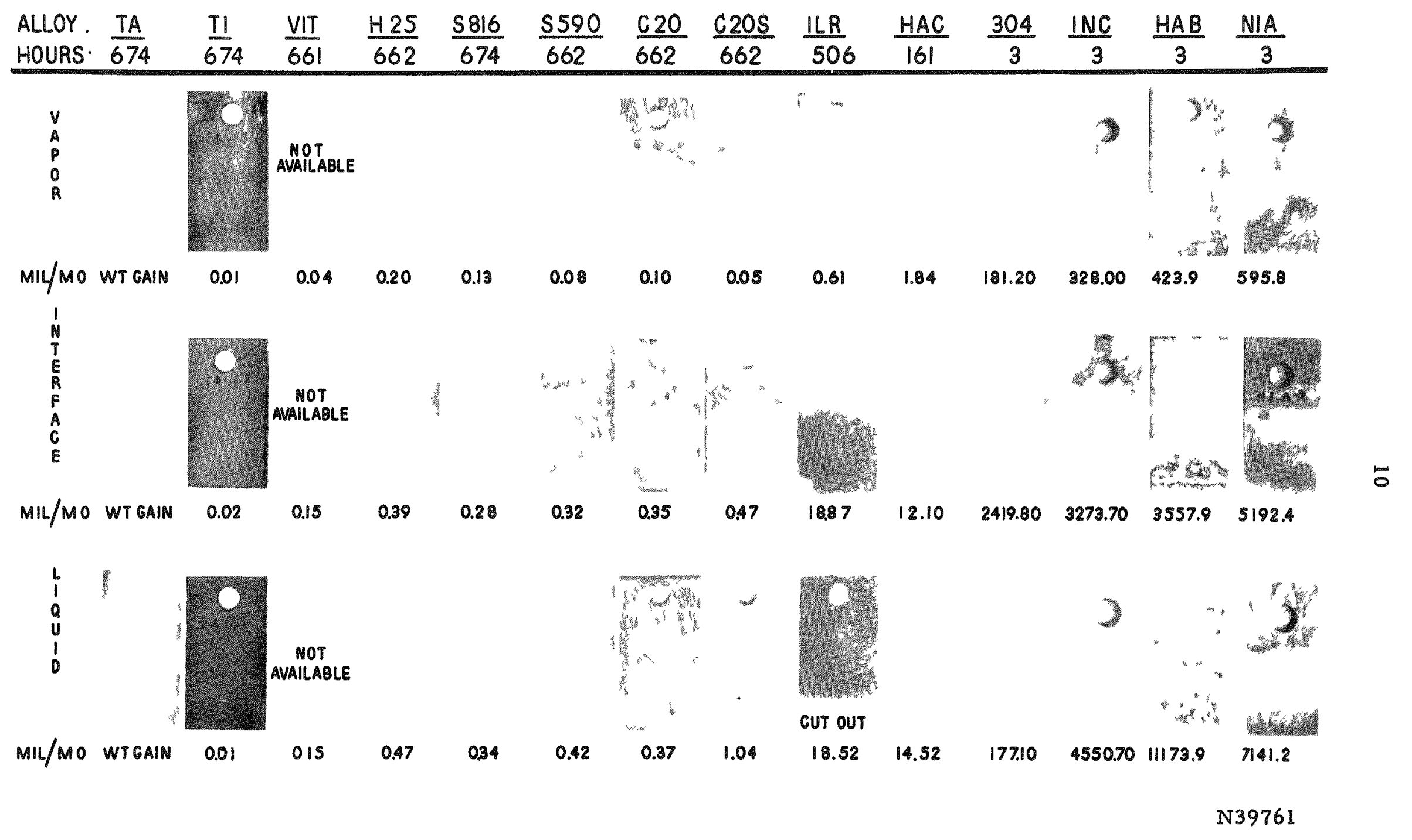

FIGURE 5. SPECIMENS FOLLOWING EXPOSURE IN 3 M ZIRCEX SOLUTIONS (BOILING) 


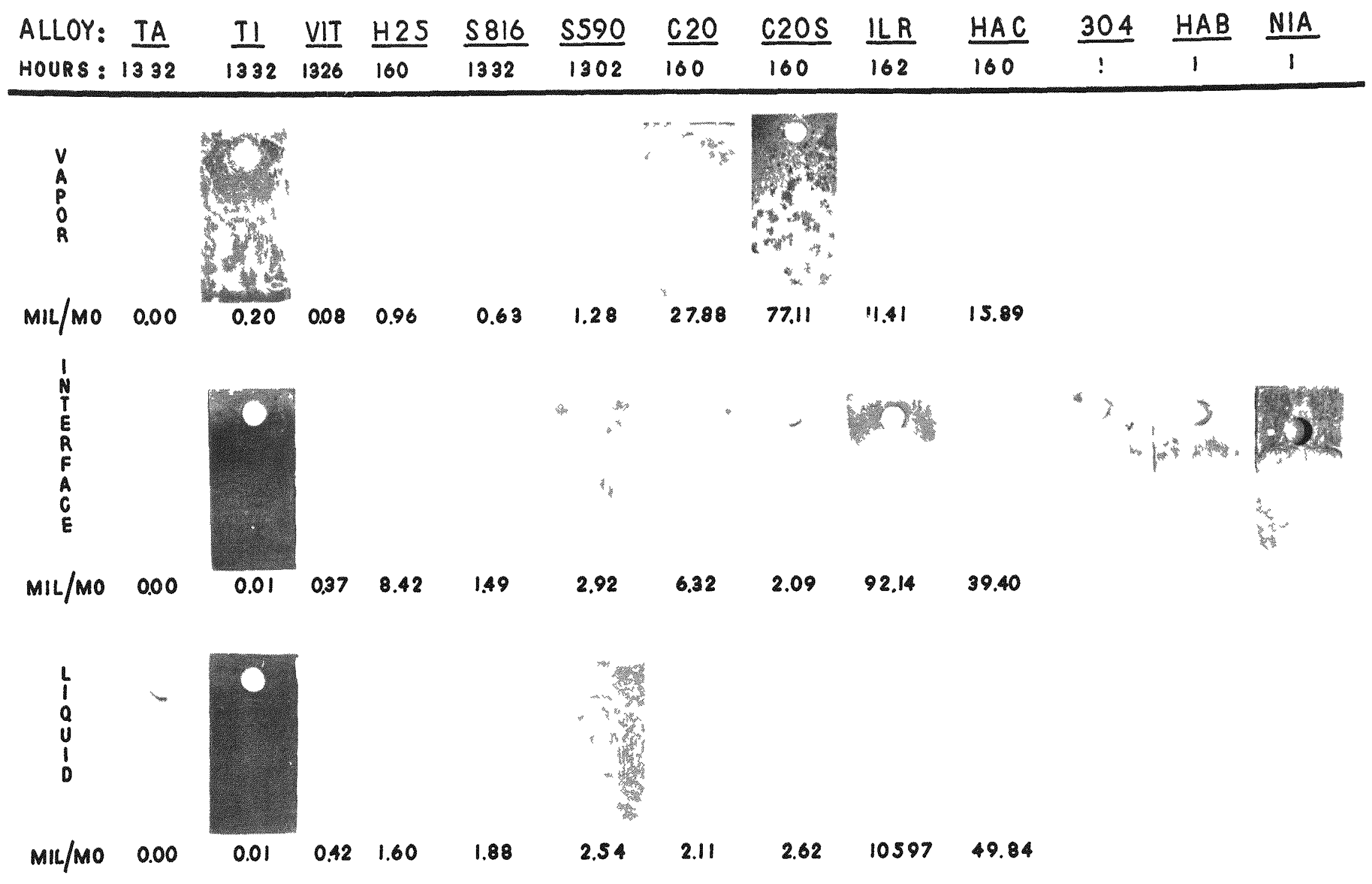

FIGURE 6. SPECIMENS FOLLOWING EXPOSURE IN $5 \mathrm{M}$ ZIRCEX SOLUTIONS (BOILING) 
TABLE 3. REPRESENTATIVE CORROSION RESULTS IN $15 \mathrm{M}$ (STARTING COMPOSITION) BOILING ZIRCEX SOLUTIONS

HCl gas bubbled through solutions continuously.

\begin{tabular}{|c|c|c|c|c|c|c|}
\hline \multirow[b]{2}{*}{ Specimen } & \multirow[b]{2}{*}{$\begin{array}{l}\text { Specimen } \\
\text { Position }\end{array}$} & \multicolumn{4}{|c|}{$\begin{array}{l}\text { Corrosion Rate for Indicated } \\
\text { Exposure, mils per month }\end{array}$} & \multirow[b]{2}{*}{ Remarks } \\
\hline & & $\begin{array}{c}1 \\
\text { Week } \\
\end{array}$ & $\begin{array}{c}2 \\
\text { Weeks } \\
\end{array}$ & $\begin{array}{c}3 \\
\text { Weeks } \\
\end{array}$ & $\begin{array}{c}4 \\
\text { Weeks } \\
\end{array}$ & \\
\hline \multirow[t]{3}{*}{ Tantalum } & Vapor & $g$ & $\mathrm{~g}$ & g & $\mathrm{g}$ & \\
\hline & Interface & $g$ & $g$ & $g$ & $\mathrm{~g}$ & \\
\hline & Liquid & $g$ & $g$ & $\mathrm{~g}$ & $g$ & \\
\hline \multirow[t]{3}{*}{ Carpenter 20} & Vapor & 1.3 & 0.9 & 1.3 & 1.6 & \\
\hline & Interface & 1.2 & 0.9 & 1.1 & 1.3 & \\
\hline & Liquid & 1.2 & 1.1 & 1.3 & 1.4 & \\
\hline \multirow{3}{*}{$\begin{array}{r}\text { Haynes } 21 \\
\text { (as cast) }\end{array}$} & Vapor & 1.1 & 1.7 & - & -- & \\
\hline & Interface & 1.2 & 6.7 & -- & -- & \\
\hline & Liquid & 1.8 & 31.0 & -- & -- & \\
\hline \multirow{3}{*}{$\begin{array}{c}\text { Haynes } 21 \\
\text { (rolled) }\end{array}$} & Vapor & 0.9 & 0.9 & 1.0 & 1.1 & \multirow{3}{*}{$\begin{array}{l}\text { Rates essentially un- } \\
\text { changed after } 8 \\
\text { weeks of exposure }\end{array}$} \\
\hline & Interface & 1.2 & 1.1 & 1.2 & 1.2 & \\
\hline & Liquid & 1.3 & 1.9 & 2.0 & 2.0 & \\
\hline \multirow{3}{*}{$\begin{array}{l}\text { Titanium } \\
\text { (75A) }\end{array}$} & Vapor & 0.0 & 0.0 & $\mathrm{~g}$ & $g$ & \multirow{3}{*}{$\begin{array}{l}\text { Rates essentially un- } \\
\text { changed after } 16 \\
\text { weeks of exposure }\end{array}$} \\
\hline & Interface & $\mathrm{g}$ & $\mathrm{g}$ & $\mathrm{g}$ & g & \\
\hline & Liquid & $g$ & $g$ & g & $g$ & \\
\hline \multirow[t]{3}{*}{$\mathrm{Ti}-6 \mathrm{w} / 0 \mathrm{Al}-4 \mathrm{w} / 0 \mathrm{~V}$} & Vapor & $\mathrm{g}$ & g & g & $g$ & \multirow{3}{*}{$\begin{array}{l}\text { Rates essentially un- } \\
\text { changed after } 16 \\
\text { weeks of exposure }\end{array}$} \\
\hline & Interface & $g$ & $g$ & $g$ & $\mathrm{~g}$ & \\
\hline & Liquid & $\mathrm{g}$ & g & g & $\mathrm{g}$ & \\
\hline \multirow[t]{3}{*}{$\begin{array}{l}\text { Titanium } \\
(\mathrm{RC}-55)\end{array}$} & Vapor & $\mathrm{g}$ & 0.1 & 0.1 & $\begin{array}{l}\text { Failed } \\
\text { rapidly }\end{array}$ & \\
\hline & Interface & 0.0 & 0.2 & 0.2 & $\mathrm{~g}$ & \\
\hline & Liquid & 0.0 & 0.5 & 0.5 & 0.3 & \\
\hline \multirow[t]{3}{*}{ Type S-816 } & Vapor & 1.6 & 1.8 & 1.7 & $\begin{array}{l}\text { Failed } \\
\text { rapidly }\end{array}$ & \\
\hline & Interface & 2.0 & 2.4 & 2.5 & Ditto & \\
\hline & Liquid & 1.8 & 2.7 & 3.1 & 4.1 & \\
\hline
\end{tabular}

Note: $g$ indicates a very small gain in weight of the specimen during the exposure. The starting composition of these solutions was $15.0 \mathrm{M} \mathrm{HNO}_{3}, 0.4 \mathrm{MUO}_{2}\left(\mathrm{NO}_{3}\right)_{2}$. 
To provide additional information along these lines, a series of experiments was conducted to examine the corrosive or passivating action of various gases on titanium in azeotropic $\mathrm{HCl}$ solutions. The gases $\mathrm{N}_{2} \mathrm{O}, \mathrm{NO}, \mathrm{NO}_{2}, \mathrm{NOCl}$, and chlorine were passed singly through a system containing boiling $6 \mathrm{M} \mathrm{HCl}$. In one test, pieces of $75 \mathrm{~A}$ titanium were placed at the vapor, interface, and liquid positions in the flask and the gas bubbled through the solution. In the other tests, the specimens were exposed in the vapor only and the gas was passed above the solution.

Table 4 summarizes the corrosion rates for the titanium specimens exposed in the liquid and vapor positions. It can be seen that the corrosion rates were high and approximately the same for specimens exposed to $\mathrm{N}_{2} \mathrm{O}$ and $\mathrm{NO}$ as for those exposed to azeotropic $\mathrm{HCl}$.

The corrosion of vapor-phase specimens was inhibited almost completely by $\mathrm{NO}_{2}$ and chlorine. The $\mathrm{NO}_{2}$ also imparted a considerable amount of inhibition to the liquidphase specimens. Chlorine showed no inhibition with liquid-phase specimens.

Other tests showed that the presence of uranium in azeotropic $\mathrm{HCl}$ will inhibit the corrosion of titanium specimens submerged in the boiling liquid. This would account for the resistance of the specimens to the liquid phase during catastrophic attack of the specimens exposed in the vapor phase.

The hydrochlorination of certain fuels, such as those with a $\mathrm{UO}_{2}$ core, may leave a low-chloride residue after volatilization of the $\mathrm{ZrCl}_{4}$. Materials for such service were evaluated in boiling solutions of $5 \mathrm{M} \mathrm{HNO}_{3}, 0.4 \mathrm{M} \mathrm{UO}_{2}\left(\mathrm{NO}_{3}\right)_{2}$, containing $500 \mathrm{ppm}$ chloride. Tantalum, titanium, Vitallium, Haynes 25, Type S-816, Type S-590, Carpenter 20, Carpenter 20 stabilized, and Types 347 and 304 ELC stainless steel showed rates of less than 1 mil per month at an exposure time of about $4000 \mathrm{hr}$.

Another of the proposed dissolution steps following hydrochlorination would use water as the solvent, ending with a solution of UCl3. Elimination tests were run in boiling solutions of $0.4 \mathrm{M} \mathrm{UCl}_{3}$. None of the five materials considered for such a system withstood the attack for even 1 week. These materials were Carpenter 20 , Haynes 21, and Type S-816 alloys, and Type 304 ELC and Type 316 stainless steels. Serious stress-corrosion cracking was shown by the Type 316 stainless and S-816 specimens at cut edges and stencil marks. Figure 7 shows the appearance of the specimens at the conclusion of the experiments and includes values for the corrosion rates.

Cyclic Tests for Both Hydrochlorination and Dissolution Steps

As was mentioned before, the gas-phase Zircex process involves two widely different steps. In the first, the fuel element would be treated by $\mathrm{HCl}$ gas at about $600 \mathrm{C}$. Following complete hydrochlorination of the bundle, the salts would be removed by treatment with nitric acid solutions. Both steps of this process would preferably be carried out in the same vessel. If materials cannot be found to withstand such severe conditions, it will be necessary to carry out each step in independent vessels.

An experimental program has been under way with the objective of determining optimum container materials for each possible process mentioned above. The program was arranged so that the specimens were alternately exposed to conditions simulating the hydrochlorination step and the dissolution step. 
TABLE 4. THE CORROSIVE ACTION OF VARIOUS GASES ON 75A TITANIUM IN $6 \mathrm{M} \mathrm{HCl} \mathrm{SYSTEM}$

Boiling Solutions, 6-Hr Exposures

\begin{tabular}{|c|c|c|c|c|}
\hline \multirow[b]{2}{*}{$\begin{array}{c}\text { Gas } \\
\text { Composition } \\
\end{array}$} & \multicolumn{4}{|c|}{ Corrosion Rate, mils per month } \\
\hline & Gas & $\begin{array}{l}\text { Vapor Phase, } \\
\text { Bubbling Through } \\
\text { Solution }\end{array}$ & $\begin{array}{c}\text { Liquid Phase, } \\
\text { Gas Bubbling Through } \\
\text { Solution }\end{array}$ & $\begin{array}{l}\text { Vapor Phase, } \\
\text { Gas Passing Through } \\
\text { Vapor Above Solution }\end{array}$ \\
\hline None & & $\begin{array}{l}546 . \\
458 .\end{array}$ & $\begin{array}{l}1063 . \\
1046 .\end{array}$ & -- \\
\hline $\mathrm{N}_{2} \mathrm{O}$ & & $\begin{array}{l}446 . \\
373 .\end{array}$ & $\begin{array}{l}1155 . \\
1156 .\end{array}$ & $\begin{array}{l}673 . \\
644 .\end{array}$ \\
\hline NO & & $\begin{array}{l}426 . \\
372 .\end{array}$ & $\begin{array}{r}986 . \\
1017 .\end{array}$ & $\begin{array}{l}584 . \\
537 .\end{array}$ \\
\hline $\mathrm{NO}_{2}$ & & $\begin{array}{l}0.1 \\
0.5\end{array}$ & $\begin{array}{l}5.5 \\
5.2\end{array}$ & $\begin{array}{c}0.0 \\
\text { Gain }(a)\end{array}$ \\
\hline NOGl & & $\begin{array}{l}286 . \\
320 .\end{array}$ & $\begin{array}{l}1024 . \\
1002 .\end{array}$ & $\begin{array}{l}\text { Gain (b) } \\
948 .(b)\end{array}$ \\
\hline Chlorine & & $\begin{array}{l}\text { Gain } \\
\text { Gain }\end{array}$ & $\begin{array}{l}1124 . \\
1122 .\end{array}$ & $\begin{array}{l}\text { Gain } \\
\text { Gain }\end{array}$ \\
\hline
\end{tabular}

(a) Gain indicates a gain in weight of $1.3 \mathrm{mg}$ or less on a 1 by 2 -in. specimen.

(b) On a repeat run with two replicates, values of 0.2 mil per month, and a weight gain, respectively, were obtained. 


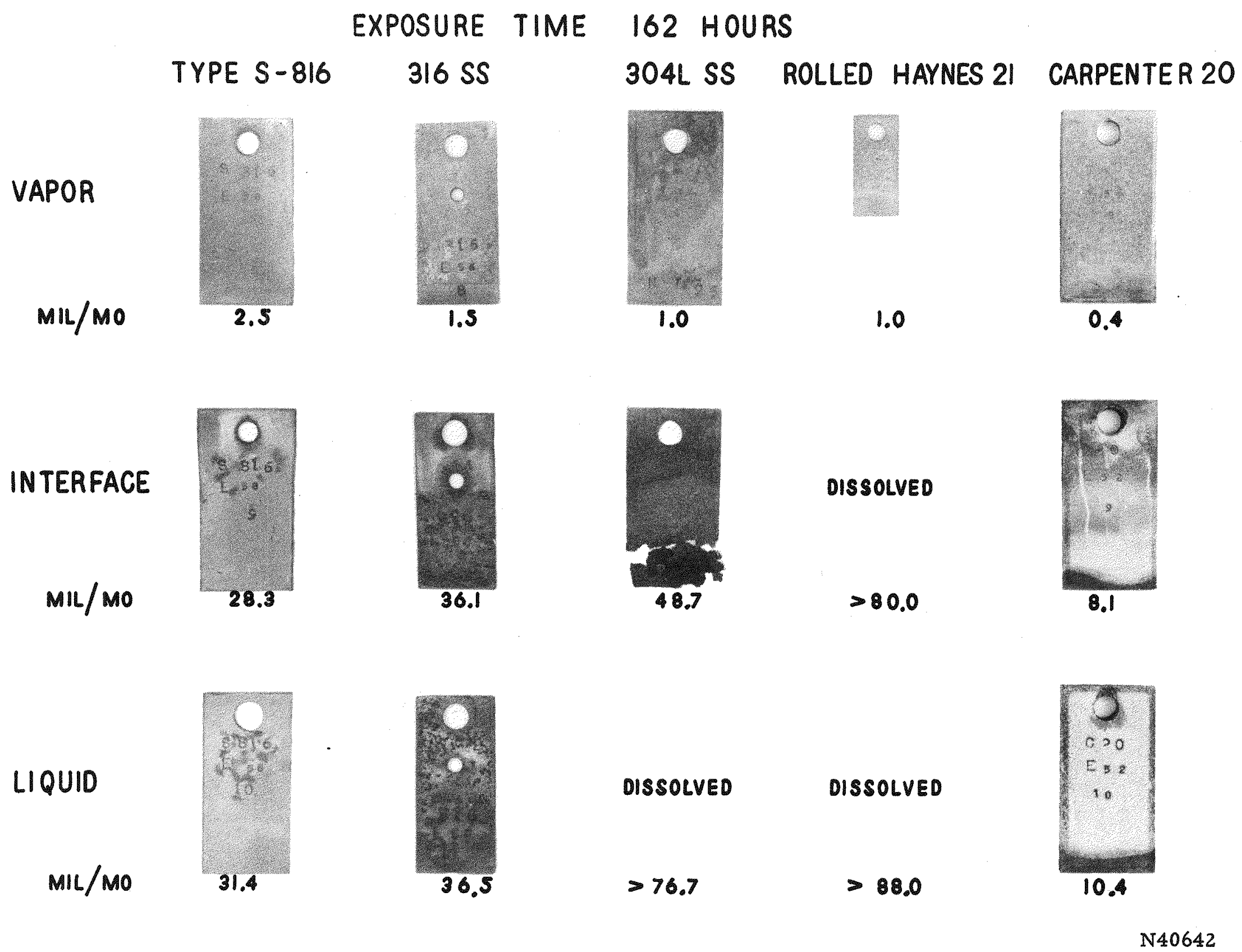

FIGURE 7. ZIRCEX ELIMINATION TESTS IN BOILING $0.4 \mathrm{MUCl}_{3}$ AQUEOUS SOLUTIONS 
In addition to the specimens which were exposed to the cyclic conditions, tensile specimens and corrosion specimens were exposed to the hot step only.

Preliminary tests showed that titanium and tantalum were unsatisfactory materials for construction of the hydrochlorinator because of excessive corrosion rates in the HClhydrogen phase at high temperatures. Accordingly, the cyclic tests were confined to alloys high in chromium, cobalt, nickel, etc. The following materials have been investigated in the two-step cycle: Type S-816, Type S-590, Haynes 21, 23, 25, 30, and 36 alloys, Carpenter 20 and Carpenter 20 stabilized, and Type 304 ELC stainless steel. Inconel, IIlium R, Hastelloys $B$ and $C$, and nickel, and those metals listed above, were exposed to just the hydrochlorination step.

A typical cycle consisted of inserting the specimens in a large tube furnace late in the evening. The furnace was flushed with argon and a mixture of hydrogen chloride and hydrogen was passed through. The heaters turned on automatically and heated the specimens to $600 \mathrm{C}$. Meanwhile, a small piece of zirconium that was inserted with each cycle was held at a temperature so that it would provide $\mathrm{ZrCl}_{4}$ in the furnace. After $11 \mathrm{hr}$ of this exposure, the $\mathrm{HCl}$ and hydrogen were shut off, the furnace thoroughly flushed with argon, and then allowed to cool with the specimens held in an argon atmosphere. The specimens were removed, rinsed in solutions of $3.0,5.0$, or $15.0 \mathrm{MHNO}_{3}$, and then placed in reflux units containing similar acid solutions to which an addition of uranium and chloride had been made. The specimens were exposed to the refluxing solutions for $2 \mathrm{hr}$, removed, rinsed with tap and distilled water, and quickly air dried. Following this, they were either returned to the furnace for another cycle or, if it were the conclusion of a multiple of five cycles, the specimens were weighed and corrosion rates, expressed as penetration in mils per 100 cycles, were calculated from the weight losses measured. The unit, mils per 100 cycles, is an arbitrary measure which is estimated to be about four times as great as the familiar mils per month unit.

The results of the corrosion rates measured for all of the liquid-phase specimens for the first 20 cycles are shown in Figures 8, 9, 10, and 11 .

Only two materials, Haynes 25 and Type S-816 alloys, showed good resistance in the two-step cyclic tests as measured by weight-loss data. These two materials consistently gave corrosion rates of 2 mils per 100 cycles, or less, even after 75 cycles from the high-temperature $\mathrm{HCl}$-hydrogen- $\mathrm{ZrCl}_{4}$ atmosphere, to solutions which were either $3 \mathrm{MHNO}$, $0.4 \mathrm{M} \mathrm{UCl} 3$, or $5 \mathrm{M} \mathrm{HNO}_{3}, 0.01 \mathrm{M} \mathrm{UCl}_{3}$. Cycling specimens of these alloys into $15 \mathrm{M} \mathrm{HNO}_{3}$ with $0.01 \mathrm{M} \mathrm{UCl}_{3}$, added at the start of each boiling period, resulted in much higher rates which gradually increased to values around 15 mils per 100 cycles after 75 cycles. These results are shown in Figures 12, 13, 14, and 15.

Metallographic sectioning and inspection of the specimens of Haynes 25 and Type S-816 exposed for 35,50 , and 75 cycles revealed that the specimens which were cycled into the boiling acid solutions underwent severe scaling and an intergranular-type of attack. Corrosion rates based on measurements of the thickness of the unattacked metal are several times greater than those calculated from weight-loss data in the 3 and $5 \mathrm{M}$ $\mathrm{HNO}_{3}$ solutions. Some of these rates are shown in the form of bars on Figures 12, 13, 14 , and 15. Based on these values, Type $\mathrm{S}-816$ alloys could not be recommended for the construction of a Zircex single-vessel hydrochlorinator dissolver. 


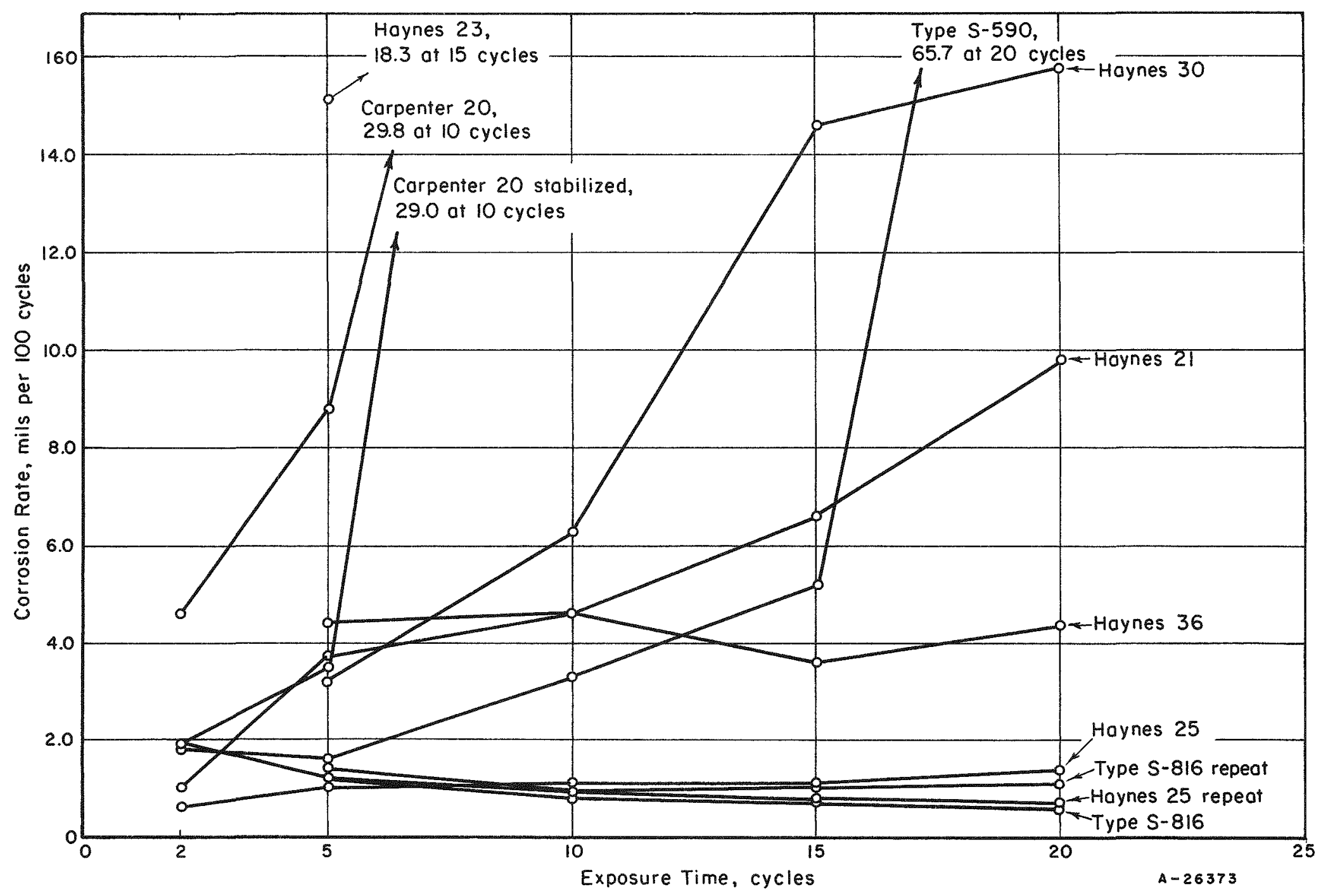

FIGURE 8. ZIRCEX CYCLIC TEST CORROSION RATES IN $3 \mathrm{M}$ HNO3, $0.4 \mathrm{M}$ UCl 3 (SUBMERGED SPECIMENS ONLY) 


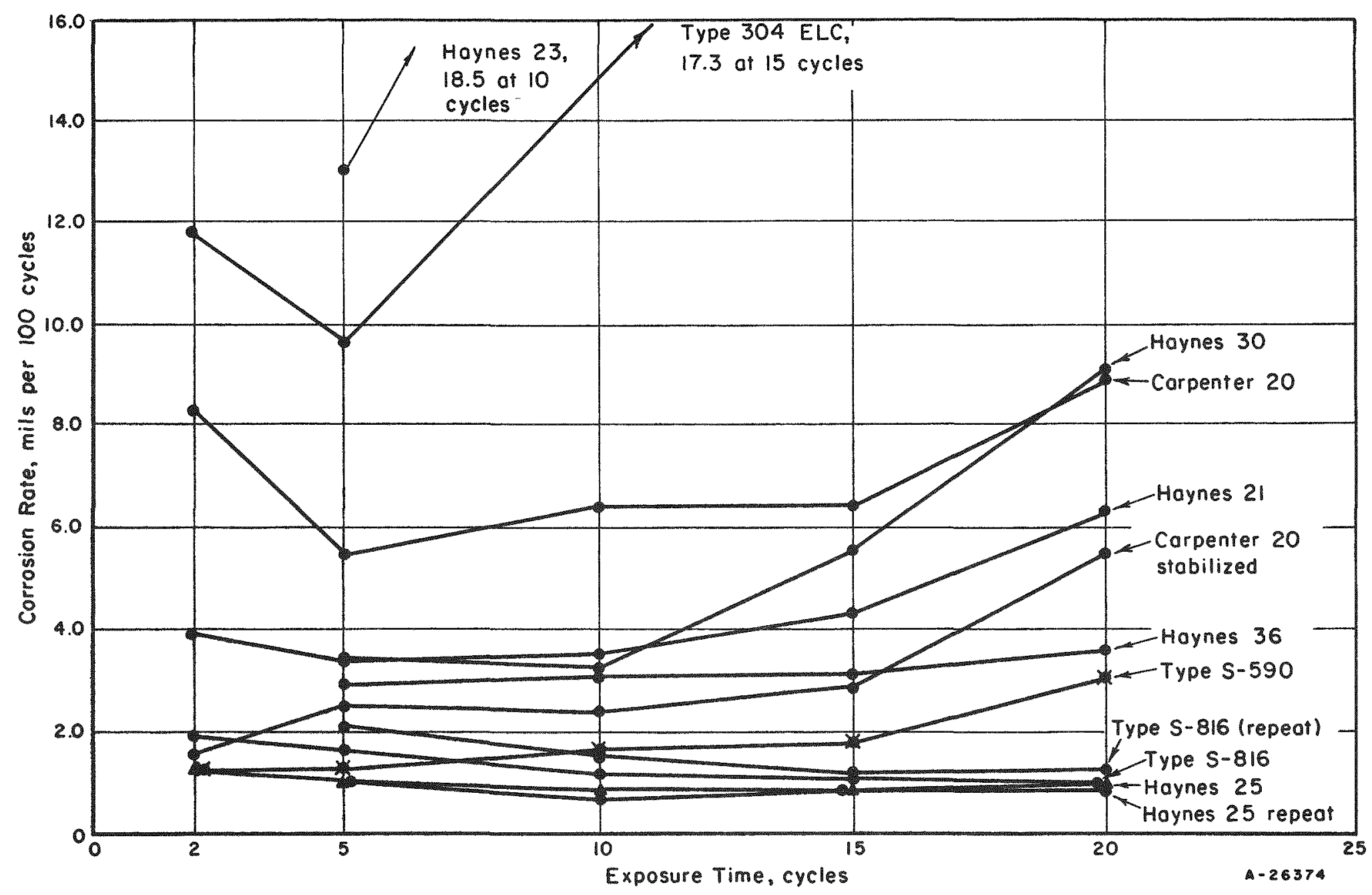

FIGURE 9. ZIRCEX CYCLIC TEST CORROSION RATES IN $5 \mathrm{MHNO}, 0.01 \mathrm{M} \mathrm{UCl} 3$, (SUBMERGED SPECIMENS ONLY) 


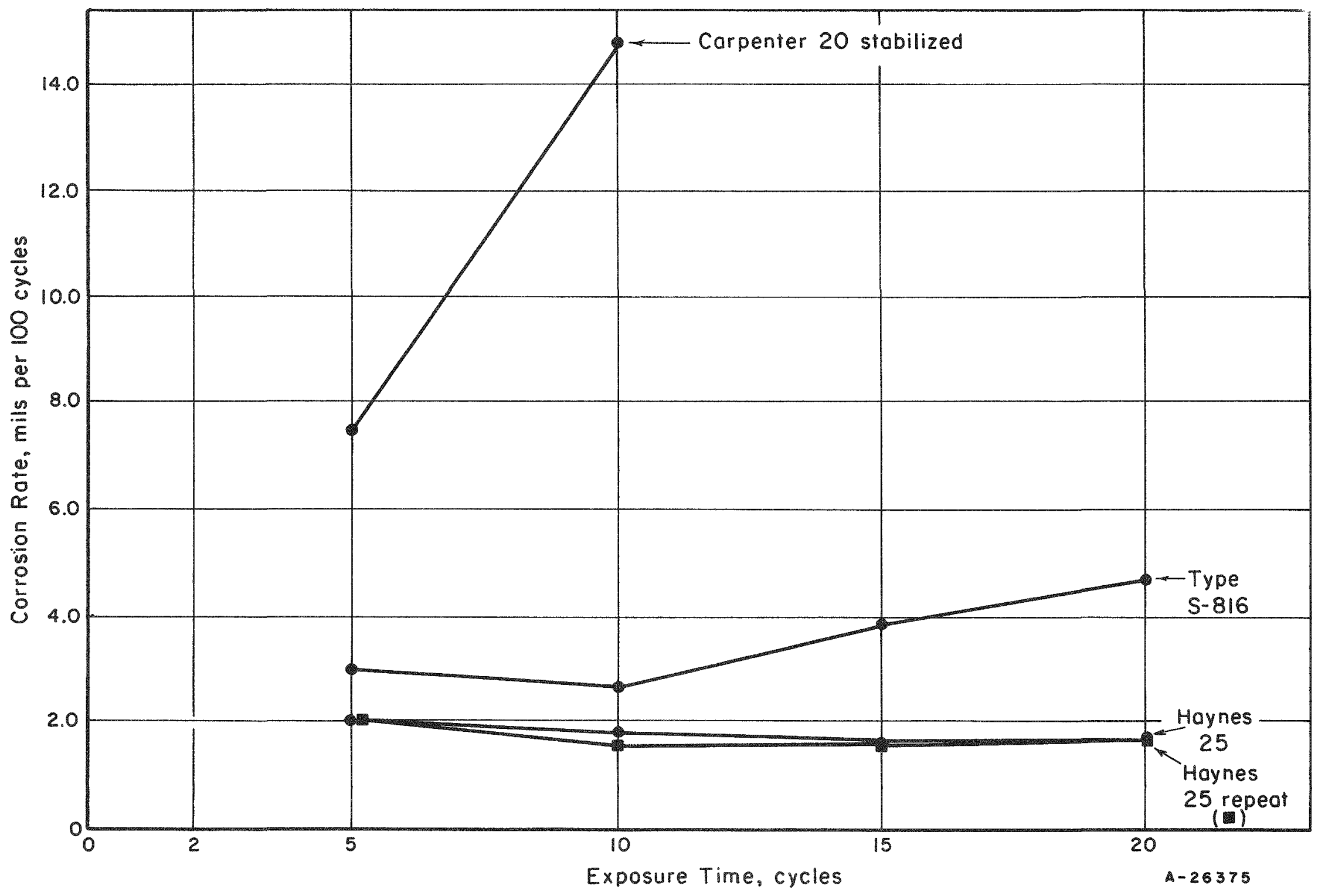

FIGURE 10. ZIRCEX CYCLIC TEST CORROSION RATES IN $5 \mathrm{M} \mathrm{HNO} 3,0.4 \mathrm{M}$ UCl3 (SUBMERGED SPECIMENS ONLY) 


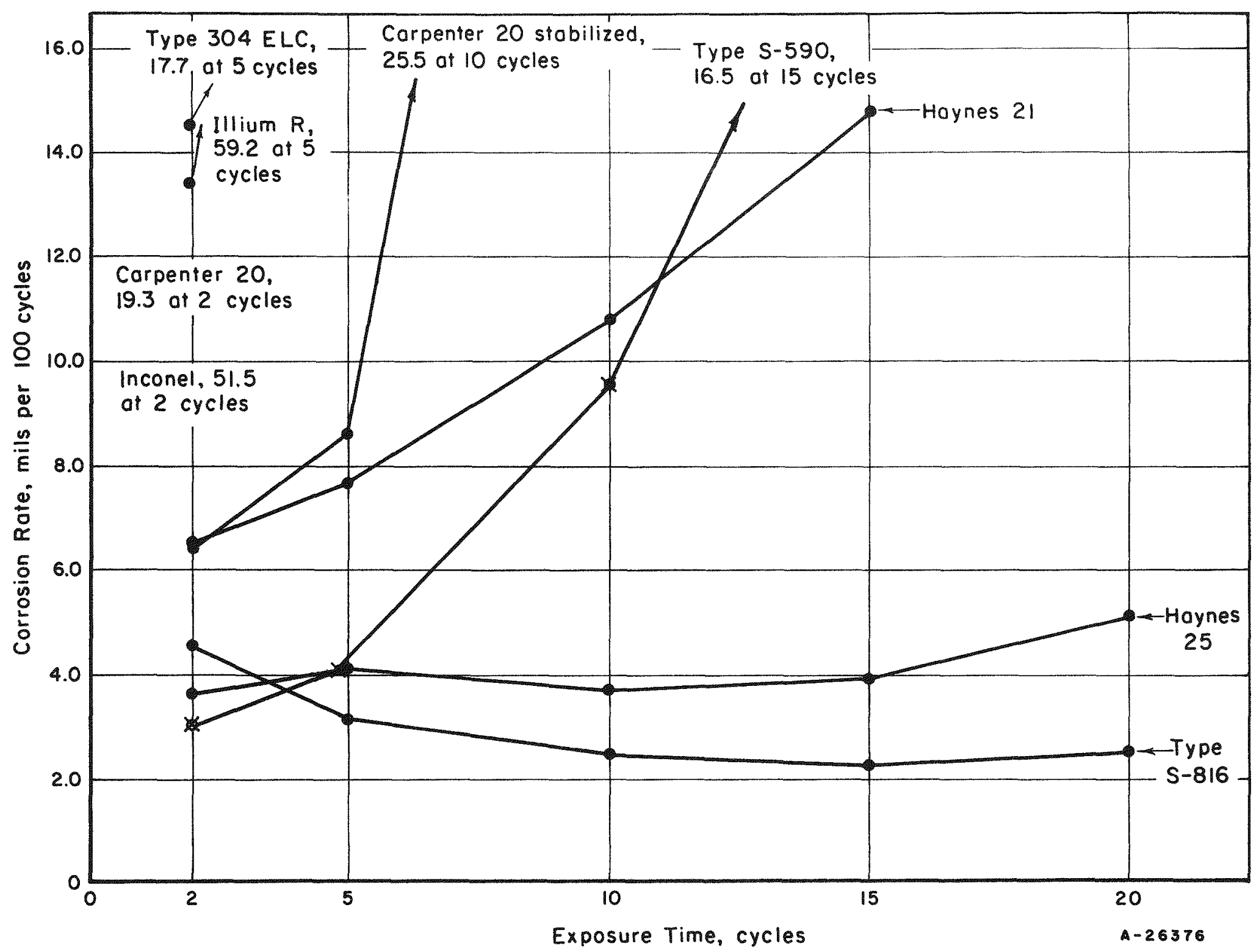

FIGURE 11. ZIRCEX CYCLIC TEST CORROSION RATES IN $15 \mathrm{M} \mathrm{HNO}_{3}, 0.01 \mathrm{M} \mathrm{UCl} 3$ (SUBMERGED SPECIMENS ONLY) 


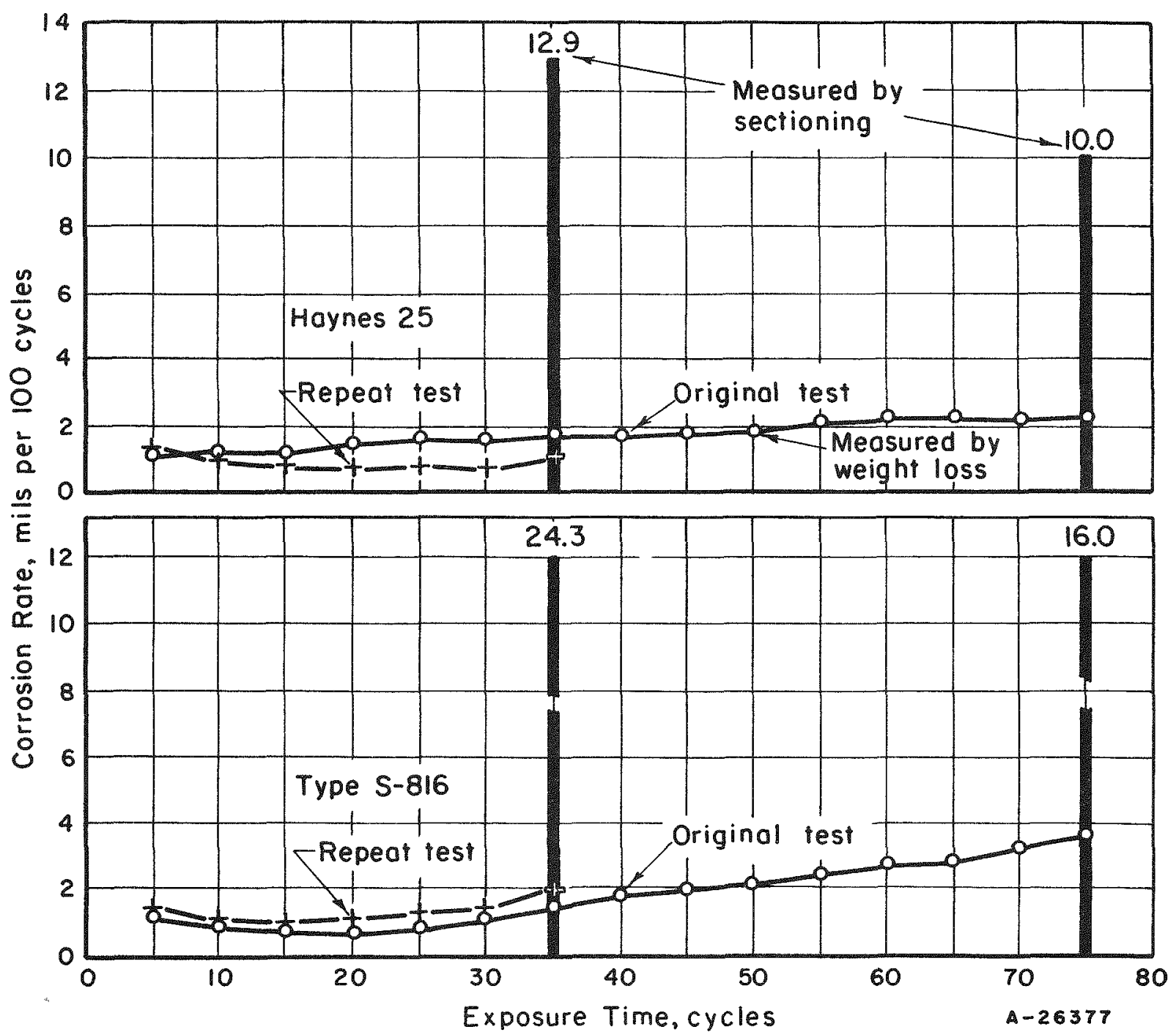

FIGURE 12. ZIRCEX CYCLIC TEST CORROSION RATES IN $3 \mathrm{MHNO} 3$, $0.4 \mathrm{M} \mathrm{UCl}_{3}$

Corrosion rates determined by metallographic methods are represented by bars. 


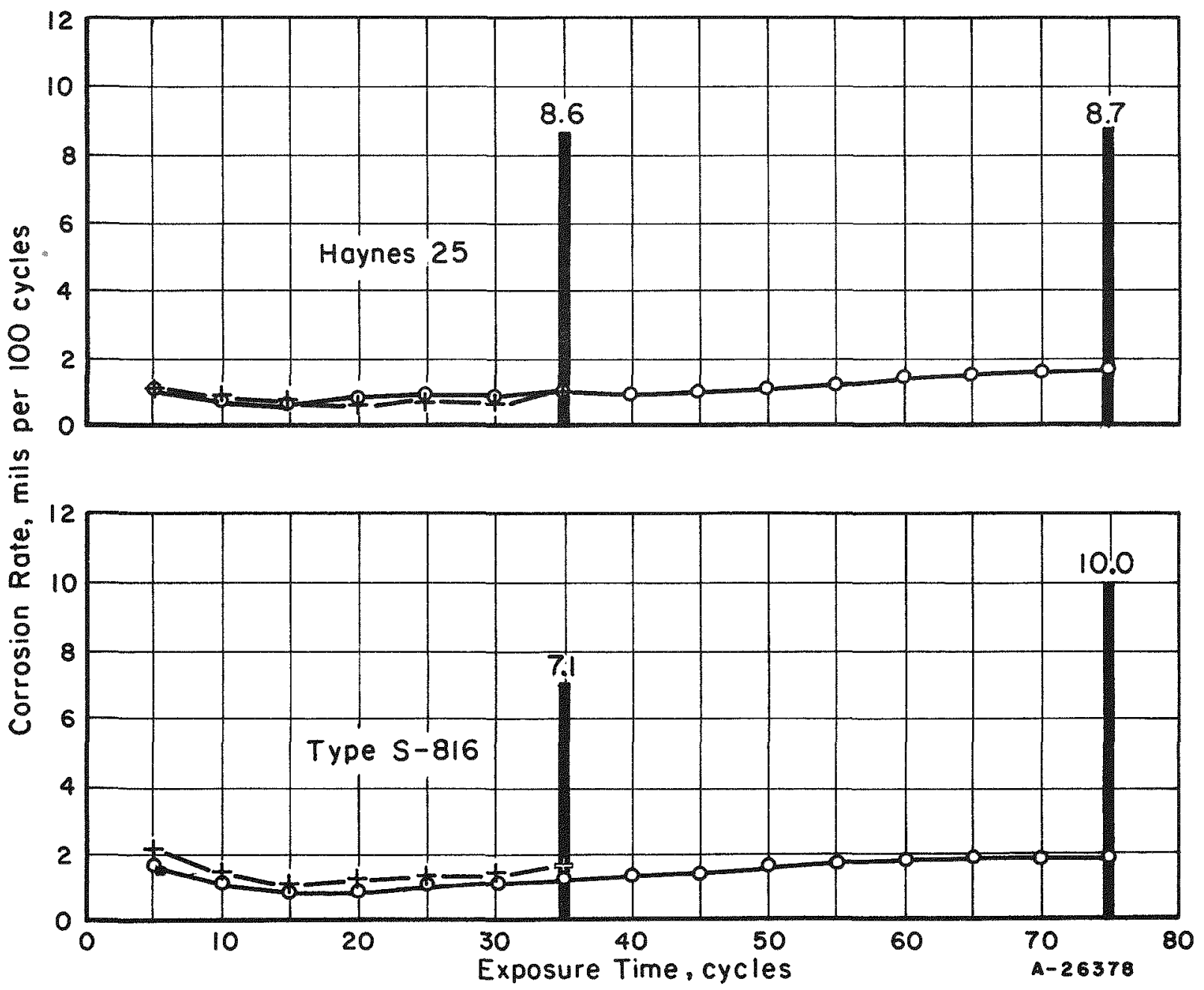

FIGURE 13. ZIRCEX CYCLIC TEST CORROSION RATES IN $5 \mathrm{M} \mathrm{HNO}_{3}$, $0.01 \mathrm{M} \mathrm{UCl}_{3}$

Corrosion rates determined by metallographic methods are represented by bars. 


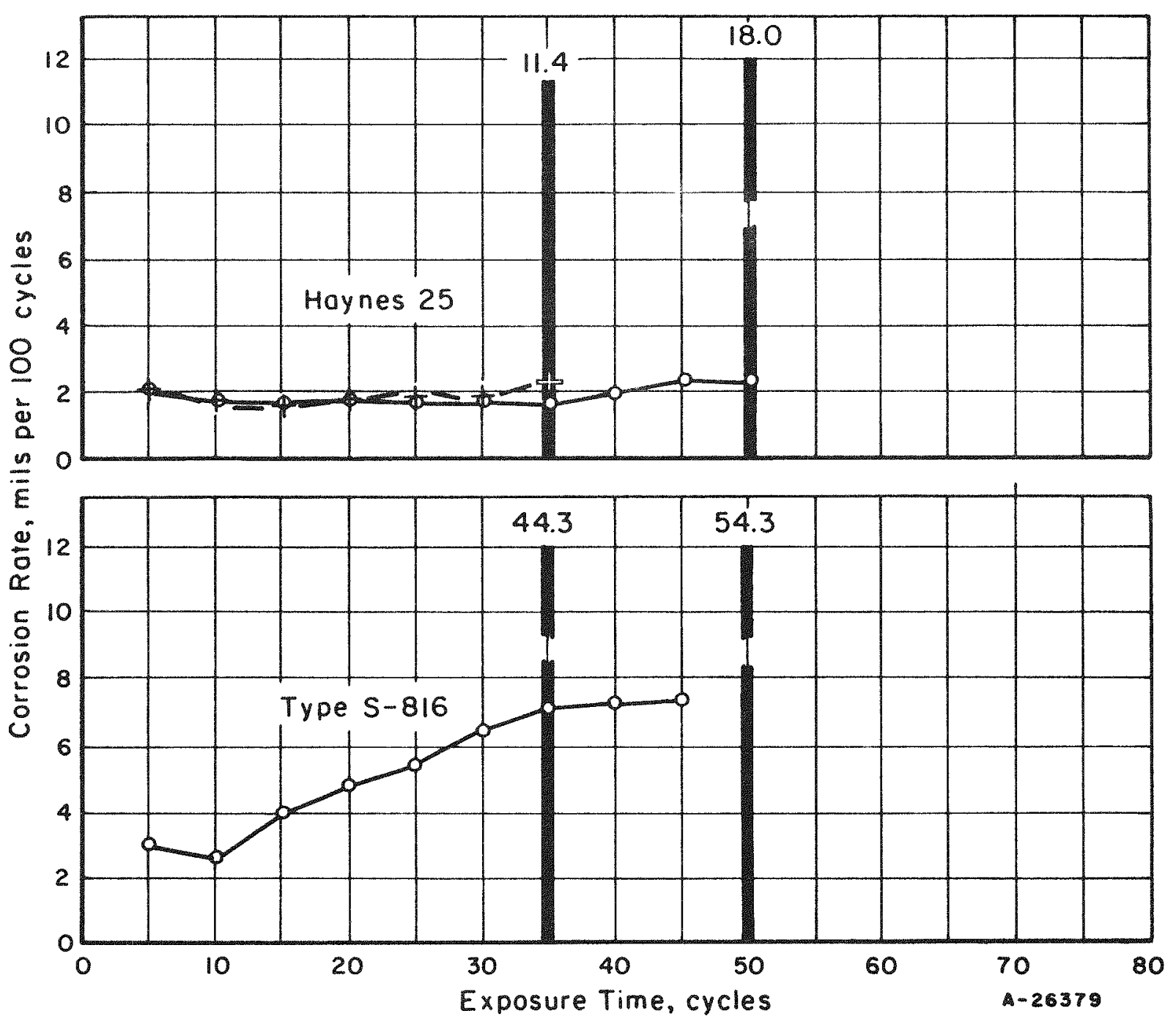

FIGURE 14. ZIRCEX CYCLIC TEST CORROSION RATES IN $5 \mathrm{M}$ HNO3, $0.4 \mathrm{MUCl}_{3}$

Corrosion rates determined by metallographic methods are represented by bars. 


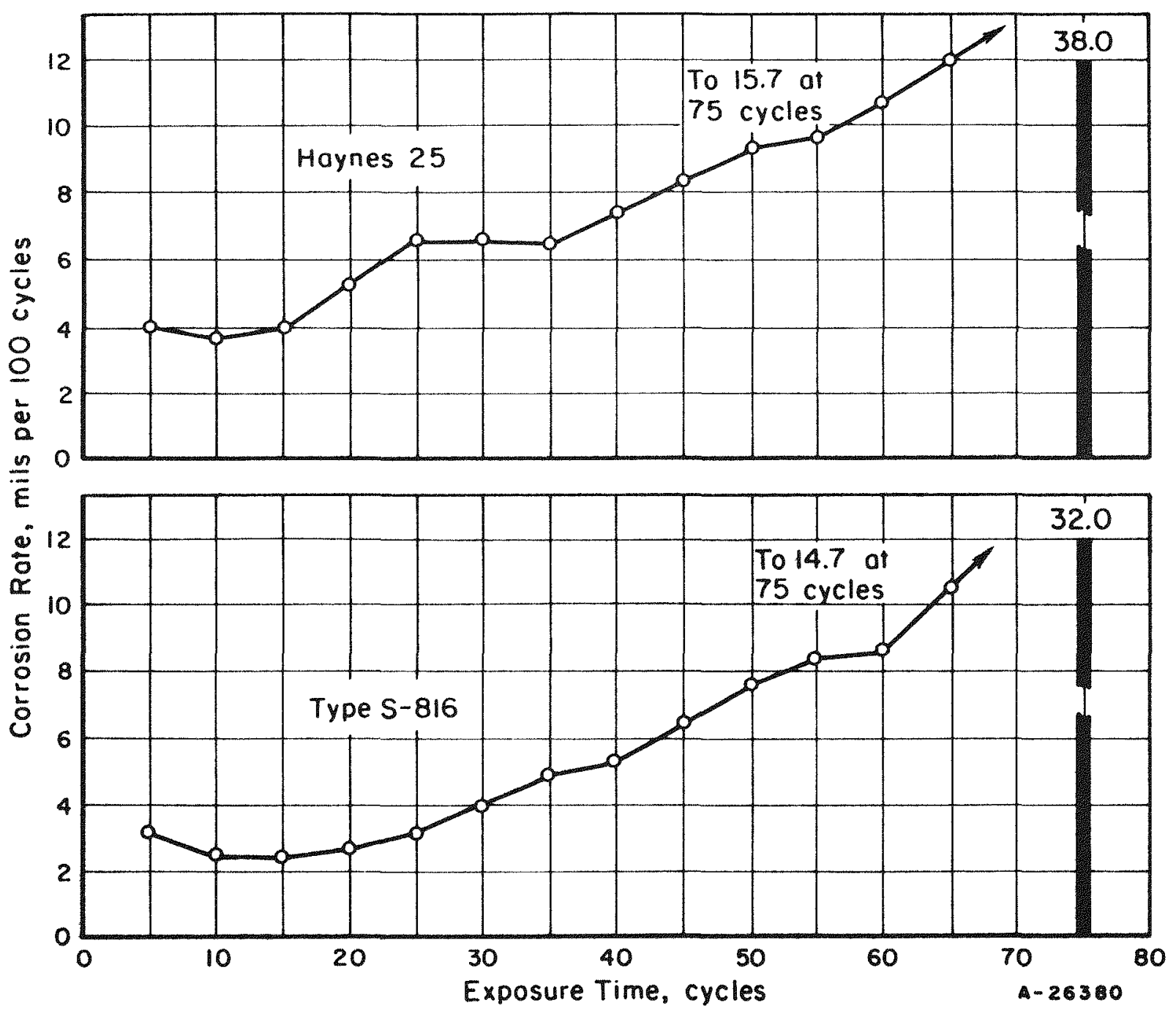

FIGURE 15. ZIRCEX CYCLIC TEST CORROSION RATES IN $15 \mathrm{M} H \mathrm{HNO}_{3}$, $0.01 \mathrm{M} \mathrm{UC}:$;

Corrosion rates cletermined by met.dlographic methods are represented by bars. 
Apparently, the occurrence of the intergranular type of attack is related to the concentration of chloride. The severity of attack, in the case of Type S-816 specimens, is several times greater in the $5 \mathrm{M} \mathrm{HNO}_{3}$ solution containing $0.4 \mathrm{MUCl}_{3}$ than in the solution of similar $\mathrm{HNO}_{3}$ concentration containing only $0.01 \mathrm{M} \mathrm{UCl}_{3}$. The difference is hardly noticeable with Haynes 25 specimens. The corrosion rates appear to be essentiaily the same at 35 cycles as at 75 cycles.

If one were to design a hydrochlorinator dissolver of sufficient thickness to withstand corrosion in the neighborhood of 3 mils per month, then the use of Haynes 25 might be considered but, at best, its use would entail calculated risks of the type which would not seem desirable in remotely controlled processes.

Incone1, Haynes 25, Types S-816, Illium R, nickel, and Hastelloys B and C showed good resistance, on the basis of weight-change data, to the hot step (see Table 5). Tensile specimens were exposed to the hot step and portions were also given bend and hardness tests. A comparison of the properties of these specimens with those of others in the as-received condition or after exposure to argon at the same temperature, $600 \mathrm{C}$, showed that Inconel, Haynes 25, Type S-816, and Illium $R$ were not affected by the hydrochlorinator. Hastelloy $C$ increased in tensile strength and hardness and decreased in elongation. Hastelloy $B$ and nickel were not tested. These results are summarized in Table 6.

It thus appears that several materials are available for the two-vessel hydrochlorination process. The optimum materials of construction for the dissolver in such a process would appear to be titanium or tantalum.

Liquid-Phase Hydrochlorination

Limited studies have been made of the corrosion produced by the liquid-phase Zircex hydrochlorination. Equipment was constructed which enabled specimens to be exposed both above the surface of and submerged in the refluxing double salt $\mathrm{AlCl}_{3} \cdot \mathrm{NH}_{4} \mathrm{Cl}$. The temperature was held at $425 \mathrm{C}$ while gaseous hydrogen chloride was passed over the surface of the salt at a low rate. Exit bubblers were used to prevent any back diffusion of air and the salt was mixed and stored in an argon atmosphere until the beginning of the test.

Twenty-three metals or alloys were screened as candidate construction materials. The results from these $24-\mathrm{hr}$ tests are shown in Table 7.

In most cases, the corrosion rate is much higher for the specimen submerged in the liquid than for that one exposed to the vapor. Gold, molybdenum, platinum, and tungsten appear to be quite resistant, but drawbacks would be encountered with each of these with regard to designing a hydrochlorination vessel. Molybdenum would seem the best choice of these, but welding techniques with this metal are not sufficiently advanced to allow fabrication of a vessel without difficulty. 
TABLE 5. RESULTS OF ZIRCEX CYCLIC TESTS

Hot Cycle Only

\begin{tabular}{|c|c|c|c|c|}
\hline \multirow[b]{2}{*}{ Specimen } & \multicolumn{4}{|c|}{ Corrosion Rate, mils per 100 cycles } \\
\hline & $\begin{array}{c}10 \\
\text { Cycles }\end{array}$ & $\begin{array}{c}30 \\
\text { Cycles }\end{array}$ & $\begin{array}{c}40 \\
\text { Cycles }\end{array}$ & $\begin{array}{c}60 \\
\text { Cycles }\end{array}$ \\
\hline Haynes 21 & 3.85 & 2.79 & Discontinued & -- \\
\hline Haynes 23 & 1.65 & 1. 94 & -- & -- \\
\hline Haynes 25 & 0.24 & $g(13)$ & $g(20)$ & 0.00 \\
\hline Haynes 30 & $g(13)$ & 0.24 & -- & $-\infty$ \\
\hline Haynes 36 & 0.13 & 0.01 & -- & -- \\
\hline Type $S-590$ & 0.75 & 0.63 & 0.48 & 0.37 \\
\hline Type S-816 & 0.27 & $g(22)$ & $g(26)$ & $g(33)$ \\
\hline Carpenter 20 & 7.57 & 6.75 & Discontinued & - \\
\hline $\begin{array}{c}\text { Carpenter } 20 \\
\text { stabilized }\end{array}$ & 7.69 & 8.25 & Discontinued & - \\
\hline Type 304 ELC & 24.65 & 20.99 & Discontinued & -- \\
\hline Inconel & $g(9)$ & $g(41)$ & $g(50)$ & $g(53)$ \\
\hline Illium R & $g(5)$ & $g(29)$ & $g(26)$ & $g(37)$ \\
\hline Hastelloy B & $g(3)$ & $g(90)$ & $g(103)$ & $g(142)$ \\
\hline Hastelloy C & $g(4)$ & $g(45)$ & $g(47)$ & $g(55)$ \\
\hline Nickel & $g(16)$ & $g(81)$ & $g(87)$ & $g(89)$ \\
\hline
\end{tabular}

Note: $g$ indicates a gain in weight, of the number of milligrams shown in parentheses, for 1 by 2 -in. specimens. 
TABLE 6. THE EFFECT OF HYDROCHLORINATION ON THE MECHANICAL PROPERTIES OF VARIOUS MATERIAIS

\begin{tabular}{|c|c|c|c|c|c|c|c|}
\hline \multicolumn{2}{|c|}{ Exposure Conditions (a) } & \multicolumn{2}{|c|}{ Tensile Strength, psi } & \multirow[b]{2}{*}{$\begin{array}{c}\text { Elongation, } \\
\text { per cent }\end{array}$} & \multicolumn{2}{|c|}{ Rockwell Hardness } & \multirow{2}{*}{$\begin{array}{l}\text { Radius to Crack } \\
\text { in Bend Test, } \\
\text { 64th in. }\end{array}$} \\
\hline$\frac{\text { Exposure Con }}{\text { Medium }}$ & onsla) & $\begin{array}{l}0.2 \text { Per Cent } \\
\text { Offset Yield }\end{array}$ & Ultimate & & $\frac{\text { Rockwell }}{\mathrm{B}}$ & $\frac{a r d n e s s}{C}$ & \\
\hline \multicolumn{8}{|c|}{ Type S-816 } \\
\hline As received & -- & 72,000 & 145,800 & 44.9 & 99 & & None ${ }^{(b)}$ \\
\hline As received & -- & 69,100 & 143,400 & 36.6 & 98,5 & -- & -- \\
\hline Argon & 110 & 74,500 & 140,600 & 28.7 & $99-100$ & -- & None \\
\hline Argon & 330 & 71,500 & 140,000 & 33.8 & -- & $23-24$ & None \\
\hline Hydrochlorinator & 110 & 77,800 & 151,100 & 33.0 & 99.5 & -- & None \\
\hline Hydrochlorinator & 330 & 70,700 & 131,100 & 26.0 & - & 19 & None \\
\hline \multicolumn{8}{|c|}{ Haynes 25} \\
\hline As received & -- & 79,500 & 157,000 & 52.8 & $102-104$ & - & None \\
\hline Argon & 110 & 87,800 & 141,200 & 23.8 & $103-104$ & $30-31$ & None \\
\hline Argon & 110 & 89,100 & 146,700 & 27.0 & $103-105$ & $30-32$ & \\
\hline Argon & 330 & 92,500 & 130,700 & 26.0 & - & $29-30$ & None \\
\hline Hydrochlorinator & 110 & 90,900 & 150,500 & 30.7 & -- & $28-29$ & None \\
\hline Hydrochlorinator & 330 & 91,200 & 151,000 & 36.8 & $105-106$ & 29 & None \\
\hline \multicolumn{8}{|c|}{ Inconel } \\
\hline As received & -- & 34,300 & 92,700 & 42.5 & 74 & -- & None \\
\hline As received & -- & 34,100 & 92,900 & 44.3 & 74.5 & - & -- \\
\hline Argon & 110 & 34,400 & 92,300 & 42.7 & 86 & -- & - \\
\hline Argon & 110 & 33,600 & 91,800 & 42.5 & 85 & -- & None \\
\hline Argon & 330 & 33,000 & 90,700 & 41.2 & 80 & - & None \\
\hline Hydrochlorinator & 110 & 34,100 & 91,800 & 44.0 & 74.5 & -- & None \\
\hline Hydrochlorinator & 330 & 36,700 & 90,800 & 43.4 & 80 & -- & None \\
\hline \multicolumn{8}{|c|}{ Hastelloy $\mathrm{C}$} \\
\hline As received & -- & 54,400 & 120,000 & 53.9 & $91-92$ & -. & None \\
\hline As received & -- & 54,500 & 121,000 & 54.0 & $91-92$ & -- & -- \\
\hline Argon & 110 & 56,300 & 121,000 & 50.6 & $93-94$ & -- & None \\
\hline Argon & 110 & 56,500 & 120,900 & 46.8 & $98-101$ & $18-22$ & - \\
\hline Argon & 330 & 57,800 & 121,000 & 41.8 & - & 18 & None \\
\hline Hydrochlorinator & 110 & 85,500 & 138,100 & 19.2 & -- & $16-18$ & None \\
\hline \multicolumn{8}{|c|}{ Mlium $\mathrm{R}$} \\
\hline As received & -- & 60,000 & 122,500 & 38.6 & $91-92$ & - & None \\
\hline Argon & 110 & 67,000 & 126,000 & 35.8 & 97 & -- & None \\
\hline Argon & 110 & 65,000 & 126,000 & 36.5 & 96 & - & -- \\
\hline Argon & 330 & 62,300 & 122,200 & 35.2 & $-\infty$ & $18-19$ & None \\
\hline Hydrochlorinator & 110 & 63,100 & 119,300 & 23.2 & - & 19 & None \\
\hline Hydrochlorinator & 330 & 63,600 & 123,000 & 35.2 & 99 & $18-19$ & 1 \\
\hline \multicolumn{8}{|c|}{ Carpenter 20} \\
\hline As received & -- & 51,800 & 94,300 & 37.3 & -- & 13 & None \\
\hline As received & - & 51,700 & 94,400 & 36.0 & -- & 12 & -- \\
\hline Argon & 110 & 55,900 & 97,900 & 35.1 & $88-90$ & -- & None \\
\hline Argon & 330 & 54,900 & 97,400 & 35.7 & -- & $12-13$ & -- \\
\hline Hydrochlorinator & 110 & 54,500 & 96,100 & 35.3 & -- & 14 & None \\
\hline Hydrochlorinator & 330 & 53,200 & 84,000 & 32.7 & 84 & - & None \\
\hline Hydrochlorinator & 330 & 53,600 & 92,400 & 33.7 & 83 & -- & -- \\
\hline
\end{tabular}


TABLE 6. (Continued)

\begin{tabular}{|c|c|c|c|c|c|c|c|}
\hline \multirow{2}{*}{\multicolumn{2}{|c|}{ Exposure Conditions(a) }} & \multicolumn{2}{|c|}{ Tensile Strength, psi } & \multirow{3}{*}{$\begin{array}{c}\text { Elongation, } \\
\text { per cent }\end{array}$} & \multirow{2}{*}{\multicolumn{2}{|c|}{ Rock well Hardness }} & \multirow{3}{*}{$\begin{array}{l}\text { Radius to Crack } \\
\text { in Bend Test, } \\
\text { 64th in. }\end{array}$} \\
\hline & & \multicolumn{2}{|l|}{0.2 Per Cent } & & & & \\
\hline Medium & Time, hr & Offset Yield & Ultimate & & B & $\mathrm{C}$ & \\
\hline \multicolumn{8}{|c|}{ Type 304 ELC } \\
\hline As received & -- & 30,100 & 83,600 & 72.7 & 70 & -- & None \\
\hline As received & -- & 30,000 & 82,600 & 70.3 & 65 & -- & -- \\
\hline Argon & 110 & 30,600 & 83,400 & 70.0 & 70 & -- & -- \\
\hline Argon & 110 & 28,300 & 83,800 & 72.5 & 68 & -- & None \\
\hline Argon & 330 & 30,600 & 84,800 & 71.8 & $76-77$ & - & $-\infty$ \\
\hline Hydrochlorinator & 110 & 23,700 & 68,400 & 67.6 & 60 & -- & 4 \\
\hline Hydrochlor inator & 330 & 20,500 & 58,400 & 52.0 & 54 & $-\infty$ & 2 \\
\hline \multicolumn{8}{|c|}{ Haynes 21} \\
\hline As received & -- & 206,700 & 233,300 & 7.3 & -- & 50 & - \\
\hline As received & -- & 184,700 & 215,100 & 8.9 & -- & 48 & 8 \\
\hline Hydrochlorinator & 110 & 188,800 & 213,800 & 0.8 & -- & 48 & 48 \\
\hline Hydrochlorinator & 330 & 188,300 & 202,100 & 1.0 & -- & 46 & 96 \\
\hline \multicolumn{8}{|c|}{ Haynes 36} \\
\hline As received & -- & 173,000 & 217,000 & 3.5 & -- & $46-50$ & 12 \\
\hline Argon & 110 & Broke in grip & - & - & -- & $49-51$ & 96 \\
\hline Hydrochlorinator & 110 & 203,800 & 228,200 & 1.9 & -- & $50-51$ & -- \\
\hline \multicolumn{8}{|c|}{ Haynes 30} \\
\hline As received & -- & 177,000 & 207,000 & 7.4 & - & $48-49$ & 16 \\
\hline Argon & 110 & 173,000 & 225,000 & 2.8 & $\ldots$ & $47-49$ & 32 \\
\hline Argon & 330 & 179,900 & 192,700 & 0.7 & -- & $48-50$ & - \\
\hline Hydrochlorinator & 110 & 181,200 & 191,100 & 3.0 & -- & $47-48$ & -- \\
\hline \multicolumn{8}{|c|}{ Haynes 23} \\
\hline As received & -- & 148,000 & 200,000 & 10.4 & -- & $44-47$ & 24 \\
\hline Argon & 110 & 164,000 & 202,000 & 3.1 & - & $49-50$ & 48 \\
\hline Argon & 330 & 158,000 & 201,100 & 3.1 & -- & $49-50$ & -- \\
\hline Hydrochlorinator & 110 & 162,000 & 198,500 & 4.8 & - & $46-47$ & -- \\
\hline
\end{tabular}

(a) Exposure in argon and in hydrochlorinator was at $600 \mathrm{C}$.

(b) No cracks at "sharp" bend radius which is less than $1 / 64$ th in. 
TABLE 7. RESULTS OF ZIRCEX LIQUID-PHASE HYDROCHLORINATION ELIMINATION TESTS

Corrosion Rates of Materials in Boiling $\mathrm{AlCl}_{3} \cdot \mathrm{NH}_{4} \mathrm{Cl}+$ Gaseous $\mathrm{HCl}$, Based on $24 \mathrm{Hr}$ of Exposure at $425 \mathrm{C}$

\begin{tabular}{|c|c|c|}
\hline \multirow[b]{2}{*}{ Specimen } & \multicolumn{2}{|c|}{ Corrosion Rate, mils per month } \\
\hline & Liquid Phase & Vapor Phase \\
\hline Platinum & 0.00 & 0.00 \\
\hline Gold & 0.01 & 0.01 \\
\hline Tungsten & 0.1 & 0.3 \\
\hline \multirow[t]{2}{*}{ Molybdenum } & $0.6^{(a)}$ & 0.4 \\
\hline & -- & 0.7 \\
\hline Nickel & 6.4 & 0.2 \\
\hline Hastelloy X & 8.2 & 0.5 \\
\hline \multirow[t]{3}{*}{ Hastelloy C } & $8.2^{(a)}$ & 0.9 \\
\hline & 12.2 & 1.6 \\
\hline & $13.0(a)$ & 1.3 \\
\hline Hastelloy C stabilized & 10.2 & 1.0 \\
\hline Inconel $\mathrm{X}$ & 10.4 & 0.2 \\
\hline Illium $R$ & 10.5 & 0.7 \\
\hline Hastelloy B & 11.4 & 2.0 \\
\hline Monel & 11.9 & 0.9 \\
\hline Type $S-590$ & 13.6 & 0.7 \\
\hline Inconel & 14.0 & 0.1 \\
\hline Hastelloy $F$ & 16.1 & 0.6 \\
\hline Type $S-816$ & 16.5 & 0.2 \\
\hline Carpenter 20 stabilized & 17.6 & 0.7 \\
\hline Hastelloy W & 18.2 & 2.4 \\
\hline Haynes 36 & $40.2^{(a)}$ & 4.2 \\
\hline Haynes 25 & 43.9 & 0.9 \\
\hline Haynes 30 & 50.6 & 0.2 \\
\hline Haynes 23 & 66.5 & 2.4 \\
\hline Haynes 21 & 82.9 & 3.8 \\
\hline
\end{tabular}

(a) Gas bubbled through melt until plugging occurred. 
Molybdenum, nickel, Hastelloy $\mathrm{X}$, and Hastelloy $\mathrm{C}$ specimens were also exposed for 7 days in the above environment. The corrosion rates with all but Hastelloy $C$ are considerably lower than those measured during the 24-hr test. Nichrome V specimens were exposed only in a 7 -day test.

\begin{tabular}{|c|c|c|}
\hline \multirow[b]{2}{*}{ Specimen } & \multicolumn{2}{|c|}{ Corrosion Rate, mils per month } \\
\hline & Liquid Phase & Vapor Phase \\
\hline$\overline{\text { Molybdenum }}$ & 0.04 & 0.02 \\
\hline Nickel & 1.19 & 0.08 \\
\hline Hastelloy $\mathrm{X}$ & 2.73 & 0.07 \\
\hline Hastelloy C & 8.39 & 1.59 \\
\hline Nichrome V & 6.24 & 0.13 \\
\hline
\end{tabular}

Metallographic examination of these specimens following the test revealed that nickel and Hastelloy $\mathrm{X}$ had undergone a very slight intergranular penetration at the surface. Similar attack was not observed on molybdenum or Hastelloy C. Nichrome $V$ has not been sectioned for metallographic examination.

Because of the indication of a leveling off in corrosion rates after relatively high initial rates, it is believed that nickel and some of the nickel-chromium alloys might be worthy of a more extensive evaluation.

\section{THE DAREX PROCESS}

Fuel elements containing stainless steel as a diluent or cladding may be treated by the Darex process. Here the element will first be dissolved in a mixture of hydrochloric and nitric acids referred to as dilute aqua regia. The chlorides will be stripped from this solution with concentrated nitric acid. Following proper adjustment of the nitric acid solution, uranium will be recovered by the usual methods of solvent extraction.

\section{Elimination-Type Tests}

Simple reflux boiling tests of an elimination type were run using solutions which imitated possible Darex solutions at various stages of the dissolution. These Darex solutions were designated as beginning, middle, and final according to their compositions. These are listed at the bottom of Figures 16, 17, and 18 .

Some of the tests were made in the presence of 50 or $100 \mathrm{ppm}$ ruthenium. This was added to represent one of the possible fission products which have been reported by ORNL to promote corrosion in other systems. Actually, in the case of these particular solutions, the presence of ruthenium produced no deleterious effects corrosionwise and may have been beneficial in some instances.

The results from the various tests are shown in Figures 16, 17, and 18. The figures show the appearance of the sample at the conclusion of the test, along with the corrosion rates and exposure times. The beginning solution was the most corrosive of the three. This probably results from both the higher acid concentration and the absence of uranium and other metal ions which may, at times, act as corrosion inhibitors. In this solution, the order of merit was from tantalum, which was unattacked, through titanium, Haynes 21, and zirconium, to Type S-816 which showed rates up to 6 mils per month. 

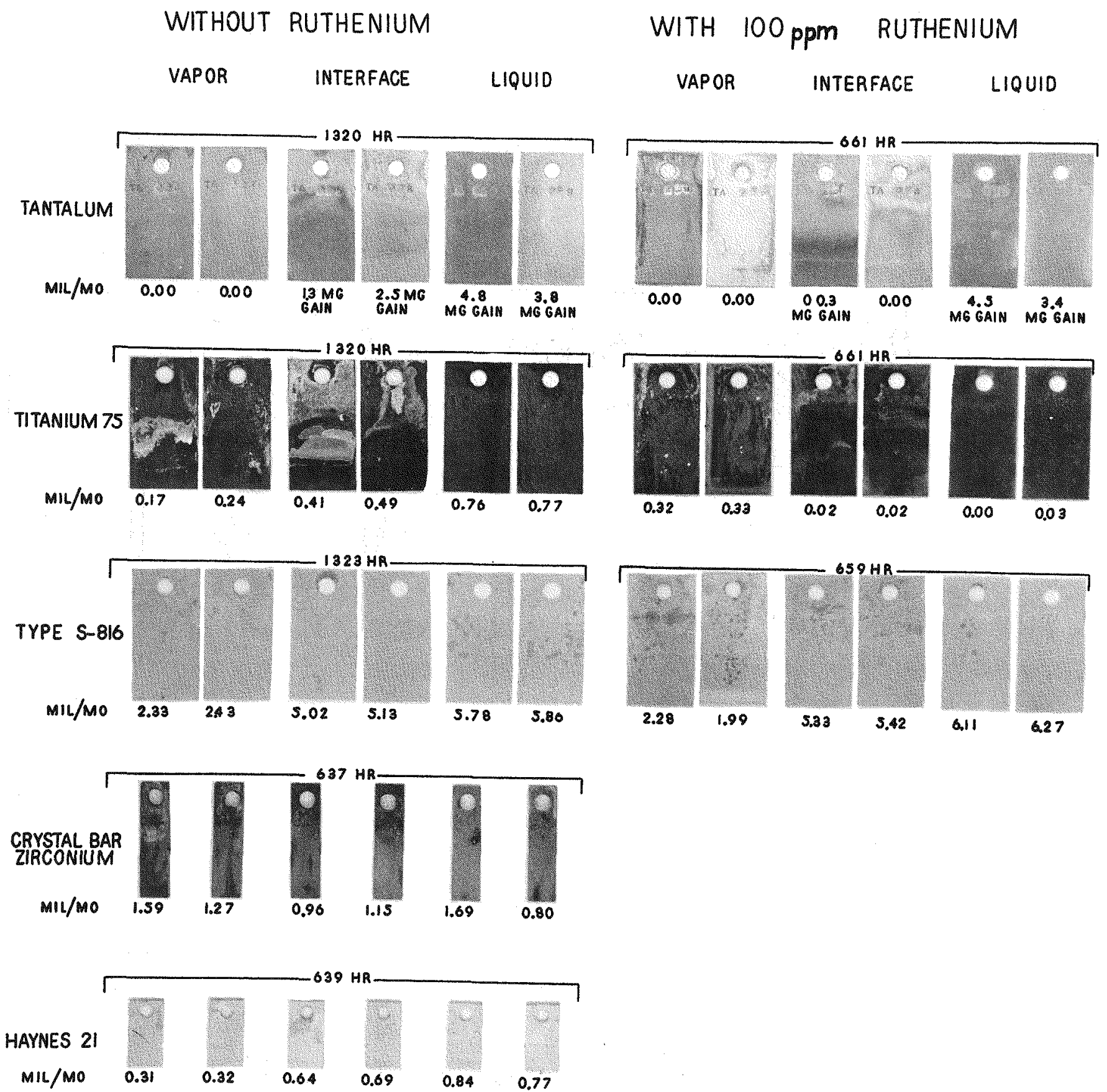

SOLUTION COMPOSITION: $\quad 7.0 \mathrm{M} \mathrm{H}, 2.0 \mathrm{M} \mathrm{Cl}^{-}, 5.05 \mathrm{M} \mathrm{NO} \mathrm{M}^{-}, 0.011 \mathrm{M} \mathrm{Fe}^{* 3}, 0.003 \mathrm{M} \mathrm{Cr}^{+3}$, $0.0012 \mathrm{M} \mathrm{Ni} \mathrm{N}^{* *}, 0.004 \mathrm{M} \mathrm{U}^{+6}$. DUPLICATE SPECIMENS.

FIGURE 16. SPECIMENS FOLLOWING EXPOSURE IN BOILING SOLUTIONS SIMULATING BEGINNING CONCENTRATIONS IN THE DAREX DISSOLVER 
WITHOUT RUTHENIUM

VAPOR INTERFACE LIQUID
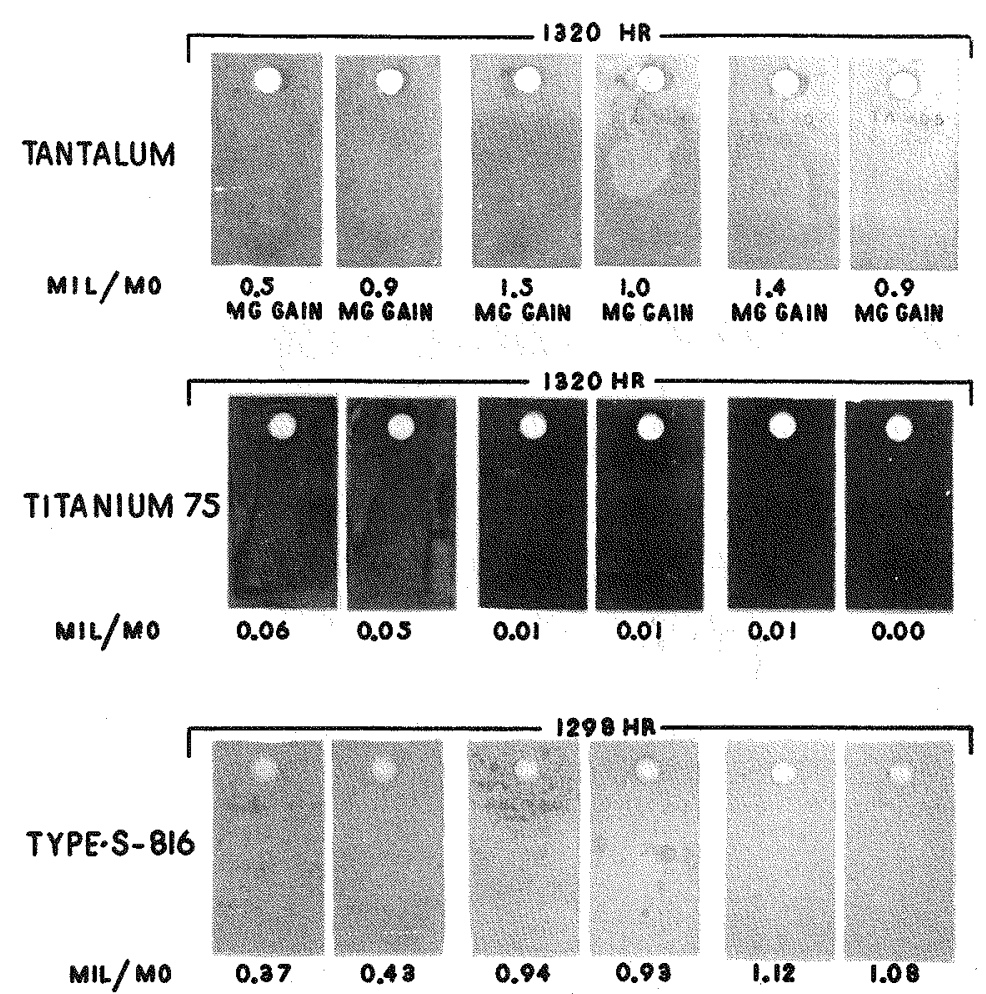

MIL/MO

0.43

0.94

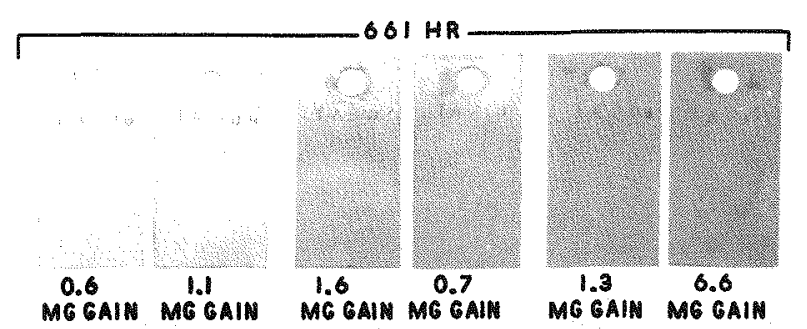

WITH 50PPM RUTHENIUM

VAPOR INTERFACE LIQUID

MG GAIN MG GAIN MG GAIN MG GAIN MGGAIN MG GAIN
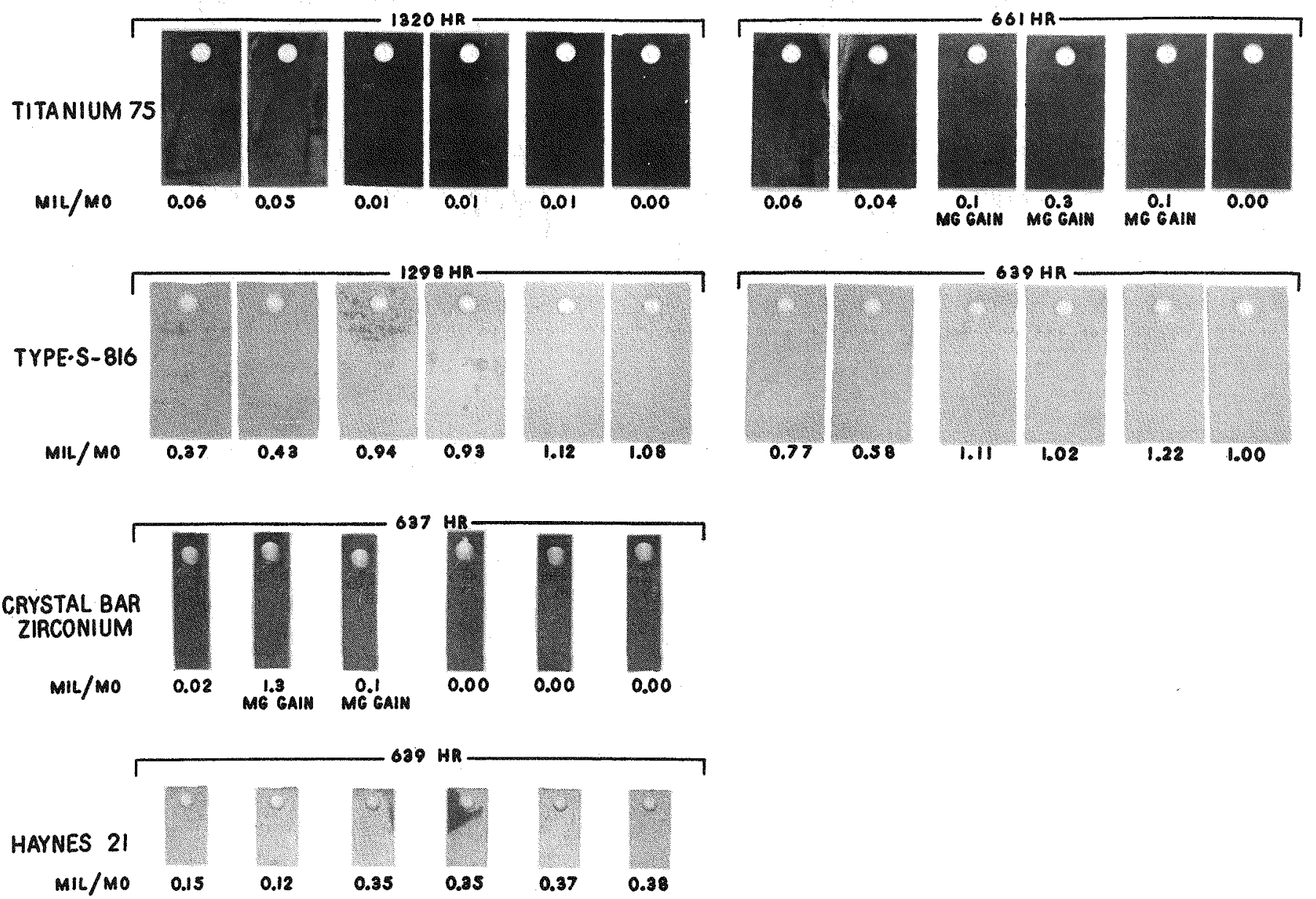

SOLUTION COMPOSITION: $\quad 4.00 \mathrm{M} \mathrm{H}^{+}, 1.89 \mathrm{M} \mathrm{Cl}^{-}, 4.73 \mathrm{M} \mathrm{NO}_{3}^{-}, 0.55 \mathrm{M} \mathrm{Fe}^{+3}, 0.15 \mathrm{M} \mathrm{Cr}^{+3}$, $0.06 \mathrm{M} \mathrm{Ni}^{+2}, 0.20 \mathrm{M} \mathrm{U}^{+6}$. DUPLICATE SPECIMENS.

FIGURE 17. SPECIMENS FOLLOWING EXPOSURE IN BOILING SOLUTIONS SIMULATING MIDDLE CONCENTRATIONS IN THE DAREX DISSOLVER 


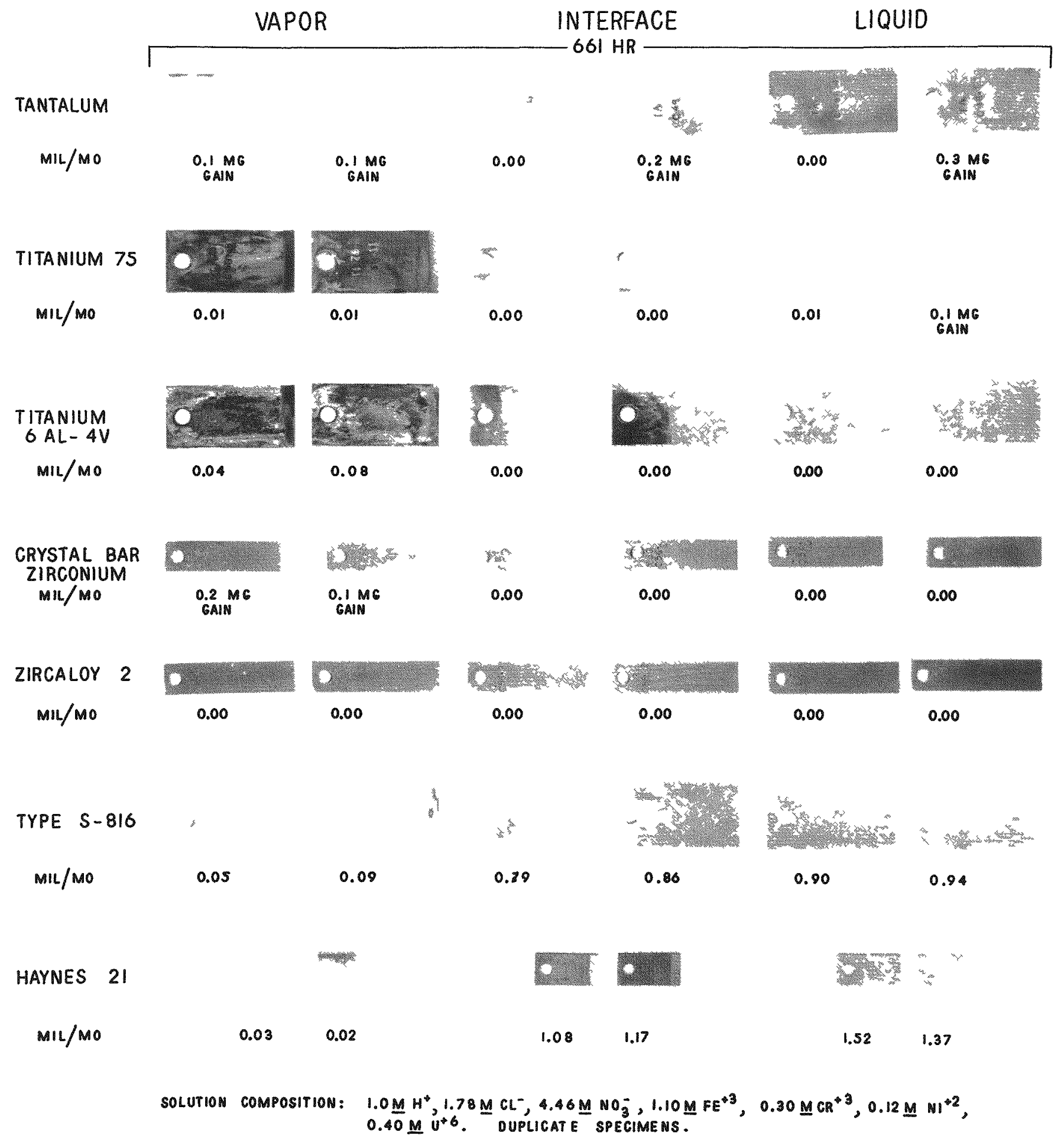

FIGURE 18. SPECIMENS FOLLOWING EXPOSURE IN BOILING SOLUTIONS SIMULATING FINAL CONCENTRATIONS IN THE DAREX DISSOLVER 
In the middle and final compositions, the Haynes 21 and Type S-816 specimens showed rates varying from about 0.1 to 1.5 mils per month. Tantalum, titanium, and zirconium were virtually unattacked. Zircaloy 2 and the titanium- $6 \mathrm{w} / \mathrm{o}$ aluminum$4 \mathrm{w} / \mathrm{o}$ vanadium alloy were also tested in solutions representing final concentrations and were found to be resistant.

All of the titanium and tantalum specimens shown in Figures 16, 17, and 18 were given bend tests. None showed any indication of embrittlement.

Prior to starting experiments with titanium, personnel at various laboratories working with the problem of pyrophoric reactions between titanium and fuming nitric acid were questioned concerning the possibility of similar reactions with Darex solutions. The consensus was that such reactions would not be expected in systems containing as much water as is present in the Darex cycles. Nothing occurred during the studies to alter this opinion.

\section{Corrosion Tests in Operating Dissolvers}

In practice, the dissolution process could be operated either batchwise or on a continuous schedule. Both operations have been simulated in corrosion tests. In flowing dissolver tests, a fresh solution of $2 \mathrm{M} \mathrm{HCl}, 5 \mathrm{M} \mathrm{HNO}_{3}$ was constantly fed to a Pyrexglass reaction vessel. The solution was heated externally to maintain it at boiling and a rod of stainless steel (5/16 in. in diameter) was continually fed by gravity through a closed tube so that only a small portion was contacted by the liquid. Dissolution of this rod was reasonably uniform once the temperature became sufficiently high to prevent the stainless from going "passive". The rod dissolved (approximately $1 \mathrm{in}$. per hr) in such a manner that it formed a conical, very sharply pointed tip. The overflow from this flask was adjusted to give enough retention time within the flask to make as good use of the acid values of the entering stream as possible, without allowing the stainless to become passive.

The other apparatus was constructed in much the same manner, except no inlet and overflow tubes were provided. A charge of fresh acid was introduced into the flask and dissolution of the stainless was continued until no more would dissolve at boiling solution temperatures. This was known as the batch dissolver.

Metal specimens were positioned at the interface between the liquid and vapor, in the vapor phase, both near the solution and high up in the condenser, and a few were totally immersed. In the case of the batch dissolver, a Soxhlet extraction tube was interposed between the flask and the condenser and specimens were exposed to alternate immersion in the condensed vapors in the extraction tube. Also, in both dissolvers, a circular piece of titanium was positioned directly under and in contact with the point of the stainless rod to see if hydrogen absorption by the titanium would occur from the galvanic cell set up between these two dissimilar metals.

The corrosion data gathered from operating the dissolvers for about 3 months, or longer, are given in Table 8 . It can be seen that titanium (75A) and tantalum were virtually unattacked. A thin blue-gray coating was formed on the titanium specimens. The titanium- $6 \mathrm{w} / \mathrm{o}$ aluminum-4 w/o vanadium alloy was somewhat less resistant. 
TABLE 8. CORROSION RATES OF METALS EXPOSED TO ACTIVE DAREX SYSTEMS

\begin{tabular}{|c|c|c|c|}
\hline \multirow{2}{*}{$\begin{array}{c}\text { Specimen } \\
\text { Material }\end{array}$} & \multirow{2}{*}{$\begin{array}{l}\text { Specimen } \\
\text { Location }\end{array}$} & \multicolumn{2}{|c|}{ Corrosion Rate, mils per month } \\
\hline & & Batch Dissolver & Flowing Dissolver \\
\hline \multirow{4}{*}{$\begin{array}{c}\text { Titanium } \\
(75 \mathrm{~A})\end{array}$} & & $1839 \mathrm{Hr}$ & $2483 \mathrm{Hr}$ \\
\hline & Vapor & $\overline{0.01-0.07}$ & $0 . \overline{02-0.03}$ \\
\hline & Interface & Gain & Gain \\
\hline & Soxhlet & 0.03 & -- \\
\hline \multirow[t]{2}{*}{ Tantalum } & Vapor & 0.01 & 0.00 \\
\hline & Interface & -- & Gain \\
\hline \multirow{4}{*}{ Haynes 21} & & & $2207 \mathrm{Hr}$ \\
\hline & Vapor & $0.24-0.43$ & 0.09 \\
\hline & Interface & -- & 0.38 \\
\hline & Liquid & 0.35 & -- \\
\hline \multirow[t]{3}{*}{ Type $\mathrm{S}-816$} & Vapor & $0.52-0.69$ & -- \\
\hline & Interface & 0.73 & -- \\
\hline & Liquid & 0.81 & - \\
\hline \multirow{3}{*}{$\mathrm{Ti}-6 \mathrm{w} / \circ \mathrm{A} 1-4 \mathrm{w} / \circ \mathrm{V}$} & & & $1000 \mathrm{Hr}$ \\
\hline & Vapor & -- & $0 . \overline{15-0.19}$ \\
\hline & Interface & -- & Gain \\
\hline \multirow{3}{*}{$\begin{array}{c}\text { Crystal-bar } \\
\text { zirconium }\end{array}$} & & & $45 \mathrm{Hr}$ \\
\hline & Vapor & -- & $\overline{67-69}$ \\
\hline & Interface & -- & $59-68$ \\
\hline
\end{tabular}

Note: Gain indicates a gain in weight of $100 \mathrm{mg}$ or less on a 1 by 2 -in. specimen. 
Haynes 21 and Type S-816 showed corrosion rates of less than 1 mil per month. Crystalbar zirconium was severely attacked and pitted under these conditions. This attack, which occurs in the presence of the gaseous decomposition products resulting from the actual dissolution of stainless steel, is certainly different from that occurring in the elimination tests where the temperatures, acid-strengths, and corrosion products are similar, but the gaseous decomposition products are absent.

In this connection, gas samples were taken during one run of the batch dissolver for analysis by the mass spectrograph. They showed that, after $1 \mathrm{hr}$, appreciable quantities of the gases $\mathrm{HCl}$, chlorine, $\mathrm{NO}_{2}$, and $\mathrm{N}_{2} \mathrm{O}$ were present. $\mathrm{HNO}_{3}$ was undoubtedly also present.

Specimens of titanium (75A) were removed at intervals during exposure and were analyzed for hydrogen by hot extraction. They were also tested for embrittlement by bending over known radii of decreasing size until cracking was observed. No hydrogen absorption nor embrittlement, as a result of exposure, could be detected.

Titanium specimens containing spot and fusion (inert gas chamber) weldments were also exposed in these systems for approximately 2 months. No deleterious effects attributable to the corrosive environment could be detected. Further work is planned in the flowing dissolver using specimens representing field-service welds. Stressed specimens will also be evaluated.

The titanium disks referred to above were not embrittled and appeared sound and unattacked at the conclusion of the tests. No hydrogen pickup was found by analysis.

A hard sludge or scale formed on the walls of the flask and on the titanium disk supporting the stainless steel rod. An $\mathrm{X}$-ray analysis showed this material to be largely amorphous in character with small amounts of spinels and metallic silicon. This deposit may prove to be objectionable in plant operation of such equipment. The development of means of removal of this scale may prove difficult.

\section{Miscellaneous Tests for Galvanic Attack}

The preceding sections have indicated that both tantalum and titanium show the greatest promise as materials of construction for processing tanks from the standpoint of resistance to over-all general attack.

In practice, the metallic elements will be in contact with the container walls. The possibility thus exists for galvanic couples to be set up. In the systems under consideration, it would be expected that the fuel-element metals would be anodic with respect to the container walls. The possibility thus exists that reduction can occur on the tantalum or titanium surface and that hydrogen could be evolved. It is known that hydrogen has deleterious effects on both the metals in question.

An experimental program was undertaken to measure the potentials, half-cell potentials, and cell currents in different systems and to evaluate the possible harmful aspects of galvanic attack. 
The polarization curves for tantalum coupled to uranium or Type 304 stainless steel were determined in boiling $2 \mathrm{M} \mathrm{HCl}, 5 \mathrm{M} \mathrm{HNO}_{3}$. Figure 19 shows these data. It can be seen that negligible polarization occurred on the stainless steel or uranium, while a considerable drop in potential occurred in the tantalum. The diagram shows that the tantalum-stainless open-circuit cell potential was 1.14 volts and the tantalum-uranium open-circuit cell potential was 1.61 volts. Gas evolution occurred on the tantalum electrode when it was coupled to uranium. None was detected when it was coupled to stainless steel.

Similar measurements were made for the system titanium-uranium-stainless steel. Figure 20 shows that considerably different polarization curves were obtained than for tantalum. First, it can be seen that all three electrodes polarized appreciably. Secondly, the cell currents were approximately 100 times greater than for tantalum couples. It is believed that this indicates more active dissolution of the anode in this case. It should also be mentioned that gas evolution occurred from the titanium electrode when coupled to either the uranium or stainless steel.

Several experiments were $r$ un in an attempt to identify the gas evolved at a titanium electrode while it was coupled to dissolving stainless steel. Analysis by means of a mass spectrograph showed that the major constituent of the gas was nitrogen, the minor constituent was water, and there were traces of hydrogen, $\mathrm{HCl}, \mathrm{NO}_{2}$, and oxygen present. It thus appears that the nitric acid, under these conditions, is reduced principally to nitrogen.

To study the deleterious effects of couples, electrolytic cells were set up with tantalum and titanium electrodes. In each cell, the metal in question was made cathodic by an impressed emf, to that value which it reaches in boiling $2 \mathrm{M} \mathrm{HCl}, 5 \mathrm{M} \mathrm{HNO} 3$, when in contact with dissolving uranium. Carbon rods were used for the anodes in the cells. The cells were operated continuously. Strips were cut from the electrodes at intervals and analyzed for hydrogen after being given a bend test. There was a noticeable embrittlement of the tantalum after $1500 \mathrm{hr}$. No appreciable embrittlement was detected in the titanium specimens. The results of the hydrogen analyses were not conclusive. The hydrogen content of the tantalum increased from 180 to $350 \mathrm{ppm}$ in $700 \mathrm{hr}$ and then showed little further increase at $1500 \mathrm{hr}$. No significant increase in hydrogen content was noted for the titanium. However, scaling was observed on the titanium specimens to an extent corresponding to a metal loss of 1.7 mils per month, computed on the weight loss measured after removing the scale by light abrasion. This is a much higher rate than has been observed during dissolver tests where the dissolution of stainless steel provides less difference in potential.

\section{CHLORIDE-STRIPPER STUDIES}

Tantalum and titanium specimens were exposed submerged in and above boiling refluxing solutions which were chosen to represent different stages during Zircex and Darex stripping. The starting compositions used for Darex stripping tests were 7.0, 9.0, and 10.6 molax in $\mathrm{HNO}_{3}$ and contained chromium, iron, nickel, and uranium ions in varying amounts. The solutions used for evaluating materials for Zircex stripping were 9, 11 , and 14 molar in $\mathrm{HNO}_{3}$ and contained 0.4 mole of uranium. HCl gas was bubbled 


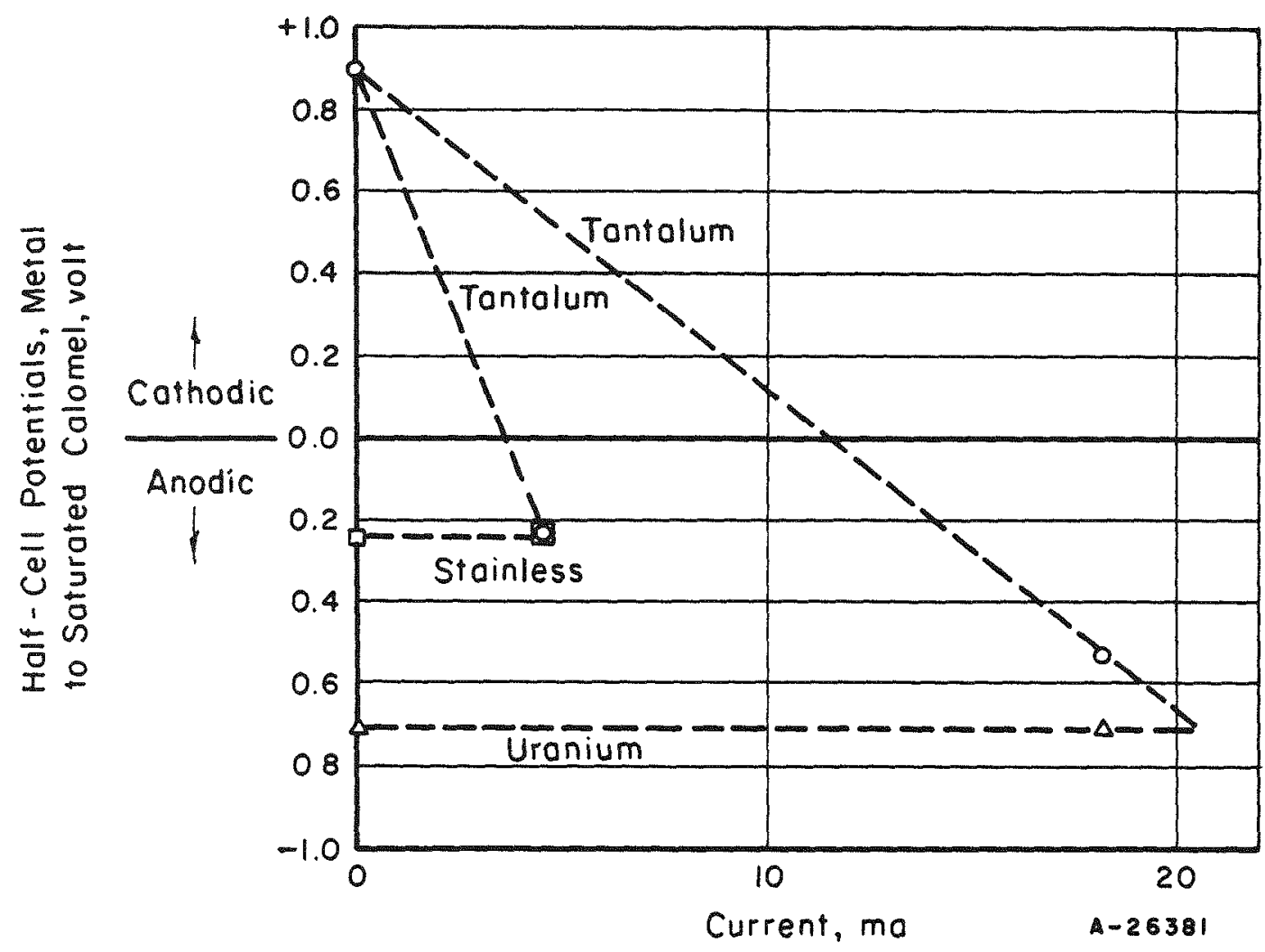

FIGURE 19. POLARIZATION CURVES EOR TANTALUM, TYPE 304 STAINLESS STEEI, AND URANIUM IN BOILING $2 \mathrm{M}$ $\mathrm{HCl}, 5 \mathrm{M} \mathrm{HNO}_{3}$ SOLUTIONS 


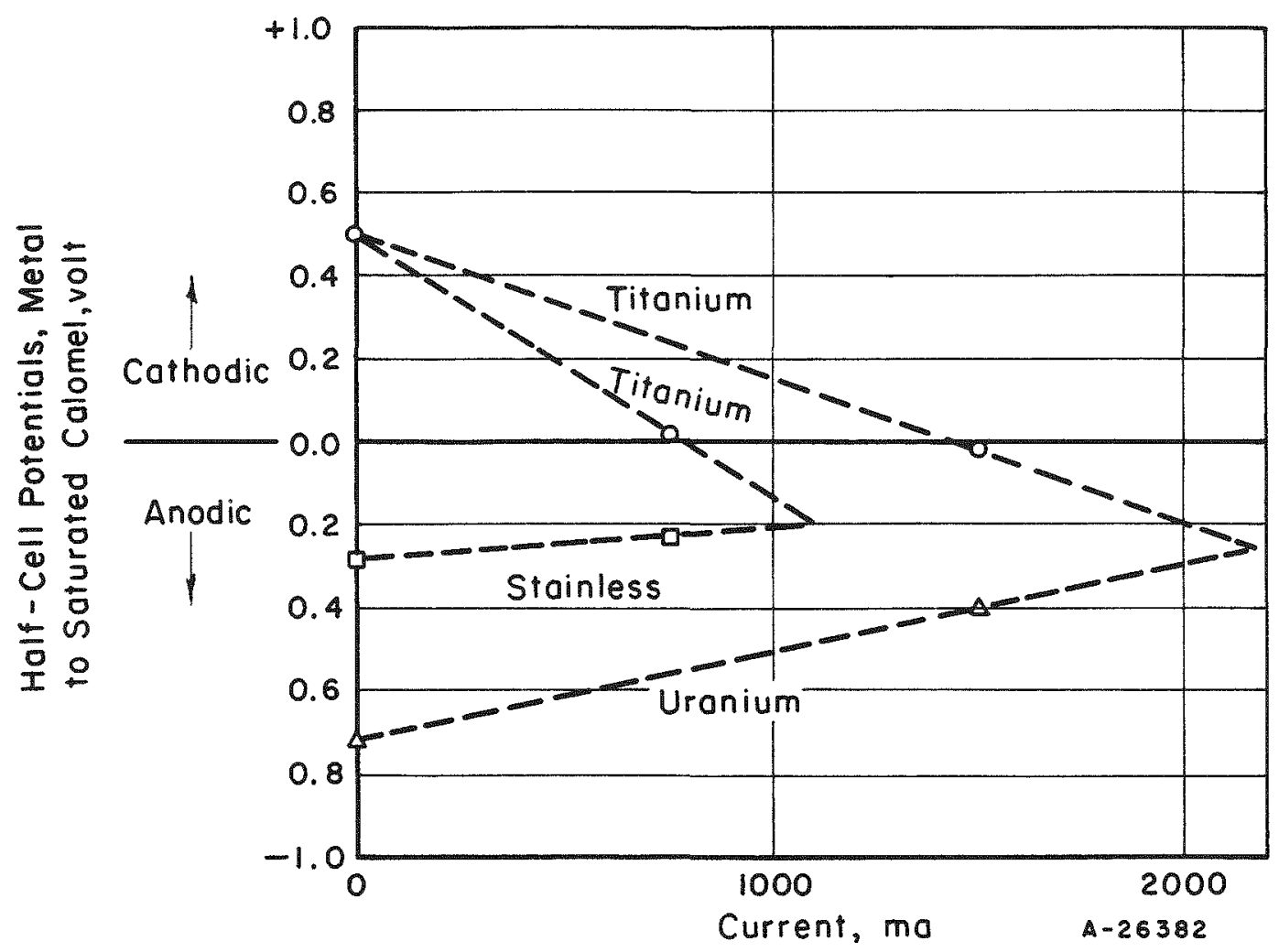

FIGURE 20. POLARIZATION CURVES FOR 75A TITANIUM, TYPE 304 STAINLESS STEEL, AND URANIUM IN BOILING $2 \mathrm{M} \mathrm{HCl,}$ $5 \mathrm{M} \mathrm{HNO}_{3}$ SOLUTIONS 
through the solutions to maintain chloride at all times. The solutions thus varied continuously in composition as a result of nitrate removal. It was found, as shown in Table 9, that titanium was quite resistant to these conditions, provided some nitrate was present to furnish passivation to the titanium. Failure of titanium can occur in a catastrophic manner if passivation is not maintained. Therefore, any contemplated design of stripper or rectifier using titanium should provide enough oxidation to maintain the metal in a passive state. As mentioned previously, the nitrate concentration necessary has not been accurately established, but it is thought to be fairly low.

Tantalum specimens were practically unaffected during the 9 weeks that they were exposed. Welded specimens of titanium were also exposed for several weeks. No selective attack could be detected in the heat-affected areas at, or near, the weldments.

\section{PUREX ACID-EXTRACTION SYSTEM}

Both the Zircex and Darex head-end processes depend upon a Purex-type acidextraction system to reclaim the uranium values from the nitric acid solution which will be adjusted following the chloride-stripping operation. Since the chloride-stripping operation may not always be completely efficient, it is possible that the chlorides which remain might lead to stress-corrosion cracking of the Type 347 stainless steel from which the extraction columns would normally be built.

Aqueous solutions were arbitrarily chosen which were: (1) high in the ions from stainless steel dissolution and low in uranium content, and (2) low in stainless steel and high in uranium. Chloride contaminations were added to these, giving a concentration range from 2 or 3 up to $10,000 \mathrm{ppm}$. One part of this aqueous phase was mixed with 3 parts, by volume, of an immiscible organic phase consisting of 1 part tributyl phosphate to 2 parts, by volume, purified kerosene. Unstressed specimens of Type 347 stainless steel and specimens stressed both to 90 per cent of the yield strength and in excess of the yield strength in the form of a " $U$ " were submerged in the chloride-bearing aqueous phase. This phase was mixed with the organic phase occasionally by shaking.

After over 6 months of exposure of these specimens at room temperature, there has been no sign of stress-corrosion cracking nor has any pitting or other noticeable corrosive attack occurred, even in the presence of $1.0 \mathrm{w} / \mathrm{o}$ chloride. Chloride contaminations, under the conditions of this test, do not seem to produce any dangerous attack.

\section{CONCLUSIONS}

\section{Zircex Technology}

A feasible corrosion-resistant container material for the single-unit Zircex hydrochlorinator-dissolver unit is not apparent at the present stage of development. The best choice is Haynes 25, provided penetration rates of approximately 3 mils per month 
TABLE 9. CORROSION RATES MEASURED IN SIMULATED ZIRCEX AND DAREX CHLORIDE-STRIPPER SOLUTIONS(A)

\begin{tabular}{|c|c|c|c|c|c|c|c|c|}
\hline \multirow[b]{2}{*}{ Specimen } & \multirow{2}{*}{$\begin{array}{c}\text { Specimen } \\
\text { Position }\end{array}$} & \multirow[b]{2}{*}{ Solution } & \multicolumn{6}{|c|}{ Corrosion Rate for Weeks of Exposure Shown, mils per month } \\
\hline & & & 1 & 4 & 9 & 12 & 16 & 19 \\
\hline \multirow[t]{3}{*}{ Tantalum } & Vapor & 9 M Zircex & 0.0 & 0.0 & $\mathrm{~g}$ & - & - & - \\
\hline & Interface & 9 M Zircex & 0.0 & $\mathrm{~g}$ & $g$ & $\infty$ & - & 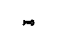 \\
\hline & Liquid & $9 \mathrm{M}$ Zircex & 0.0 & $g$ & $\mathrm{~g}$ & $\Rightarrow$ & - & - \\
\hline \multirow[t]{3}{*}{ Titanium } & Vapor & $9 \mathrm{M}$ Zircex & $\mathrm{g}$ & 0.1 & 0.2 & 0.2 & Fail & \\
\hline & Interface & 9 M Zircex & 0.1 & 0.0 & 0.1 & 0.1 & Fail & dly \\
\hline & Liquid & 9 M Zircex & 0.4 & 0.1 & 0.2 & 0.1 & Fail & dly \\
\hline \multirow[t]{3}{*}{ Tantalum } & Vapor & $11 M$ Zircex & 0.0 & 0.0 & 0.0 & - & - & $\rightarrow$ \\
\hline & Interface & 11 M Zircex & 0.0 & 0.0 & $\mathrm{~g}$ & - & - & - \\
\hline & Liquid & $11 \mathrm{M}$ Zircex & 0.0 & g & $\mathrm{g}$ & - & - & - \\
\hline \multirow[t]{3}{*}{ Titanium } & Vapor & $11 \mathrm{M}$ Zircex & 0.0 & 0.1 & 0.2 & 0.2 & 0.2 & 0.2 \\
\hline & Interface & $11 \mathrm{M}$ Zircex & 0.0 & 0.0 & 0.0 & 0.0 & 0.1 & 0.0 \\
\hline & Liquid & $11 \mathrm{M}$ Zircex & 0.1 & 0.1 & 0.0 & 0.0 & 0.1 & 0.1 \\
\hline \multirow[t]{3}{*}{ Tantalum } & Vapor & $14 \mathrm{M}$ Zircex & 0.0 & 0.0 & 0.0 & - & - & - \\
\hline & Interface & $14 \mathrm{M}$ Zircex & 0.0 & $\mathrm{~g}$ & $\mathrm{~g}$ & - & - & $\Rightarrow$ \\
\hline & Liquid & 14 M Zircex & 0.0 & $g$ & g & - & 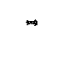 & - \\
\hline \multirow[t]{3}{*}{ Titanium } & Vapor & 14 M Zircex & 0.0 & $g$ & 0.1 & 0.1 & 0.1 & 0.1 \\
\hline & Interface & $14 \mathrm{M}$ Zircex & 0.0 & 0.0 & 0.0 & 0.0 & 0.0 & 0.0 \\
\hline & Liquid & 14 M Zircex & 0.0 & 0.0 & $\mathrm{~g}$ & $\mathrm{~g}$ & $\mathrm{~g}$ & 0.0 \\
\hline \multirow[t]{3}{*}{ Tantalum } & Vapor & 7 M Darex & 0.0 & 0.0 & 0.0 & - & - & - \\
\hline & Interface & 7 M Darex & 0.0 & 0.0 & 0.0 & - & - & - \\
\hline & Liquid & 7 A Darex & 0.0 & $\mathrm{~g}$ & $\mathrm{~g}$ & - & $\infty$ & - \\
\hline \multirow[t]{3}{*}{ Titanium } & Vapor & 7 M Darex & 0.0 & 0.0 & 0.0 & 0.0 & Fai & $\mathrm{dly}$ \\
\hline & Interface & 7 M Darex & 0.0 & 0.0 & 0.0 & 0.0 & Fai & dly \\
\hline & Liquid & 7 M Darex & 0.0 & 0.0 & 0.0 & 0.0 & 0.0 & \\
\hline \multirow[t]{3}{*}{ Tantalum } & Vapor & 9 M Darex & 0.0 & 0.0 & 0.0 & - & - & - \\
\hline & Interface & 9 M Darex & 0.0 & $\mathrm{~g}$ & $\mathrm{~g}$ & $=$ & - & $\infty$ \\
\hline & Liquid & 9 M Darex & $g$ & $\mathrm{~g}$ & g & - & $\rightarrow$ & - \\
\hline \multirow[t]{3}{*}{ Titanium } & Vapor & $9 M$ Darex & 0.0 & 0.0 & 0.0 & 0.0 & 0.0 & 0.1 \\
\hline & Interface & 9 M Darex & $\mathrm{g}$ & $g$ & $\mathrm{~g}$ & 0.0 & 0.0 & 0.0 \\
\hline & Liquid & 9 M Darex & 0.0 & $g$ & $\mathrm{~g}$ & $\mathrm{~g}$ & 0.0 & 0.0 \\
\hline \multirow[t]{3}{*}{ Tantalum } & Vapor & 10.6 M Darex & 0.0 & 0.0 & $g$ & - & - & - \\
\hline & Interface & 10.6 M Darex & $g$ & $\mathrm{~g}$ & 0.0 & - & $\infty$ & 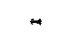 \\
\hline & Liquid & 10.6 M Darex & 0.0 & $\mathrm{~g}$ & $\mathrm{~g}$ & 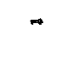 & - & - \\
\hline \multirow[t]{3}{*}{ Titanium } & Vapor & 10.6 M Darex & 0.0 & 0.0 & 0.0 & 0.0 & 0.0 & 0.0 \\
\hline & Interface & 10.6 M Darex & 0.0 & $\mathrm{~g}$ & 0.0 & 0.0 & 0.0 & 0.0 \\
\hline & Liquid & 10.6 M Darex & 0.0 & g & $\mathrm{g}$ & 0.0 & 0.0 & 0.0 \\
\hline
\end{tabular}

Note: g indicates a very small gain in weight of the specimens during the exposure.

(a) $\mathrm{HCl}$ gas was bubbled continuously through the boiling solutions whose starting compositions were as follows:

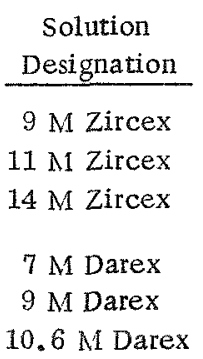

\begin{tabular}{rc}
\hline $\mathrm{HNO}_{3}$ & $\mathrm{UO}_{2}\left(\mathrm{NO}_{3}\right)_{2}$ \\
9.0 & 0.40 \\
11.0 & 0.40 \\
14.0 & 0.40 \\
7.0 & 0.40 \\
9.0 & 0.40 \\
10.6 & 0.35
\end{tabular}

Starting Molar Composition

$\begin{array}{ccc}\mathrm{Fe}\left(\mathrm{NO}_{3}\right)_{3} & \mathrm{Cr}\left(\mathrm{NO}_{3}\right)_{3} & \mathrm{Ni}\left(\mathrm{NO}_{3}\right)_{2} \\ & - & - \\ - & - & - \\ 1.10 & - & - \\ 1.10 & 0.30 & 0.12 \\ 0.97 & 0.30 & 0.12 \\ & 0.27 & 0.11\end{array}$


can be tolerated. The second choice is Type S-816, which shows even poorer resistance to corrosion (approximately $10 \mathrm{mils} / \mathrm{month}$ ). At this time, it appears that the process should be run in two steps. Several materials, such as Inconel, Haynes 25, Type S-816, Illium $R$, and Hastelloy $B$, appear promising for construction of the hydrochlorinator. The dissolution of the cold residue could then be carried out by transferring it to a container made from titanium or tantalum.

Only preliminary experiments have been completed in the alternate liquid-phase Zircex hydrochlorination system employing $\mathrm{AlCl}_{3} \cdot \mathrm{NH}_{4} \mathrm{Cl}$ and gaseous $\mathrm{HCl}$ at $425 \mathrm{C}$. Nickel and certain Hastelloys (such as $C$ and $X$ ) appear to be worth further consideration. Gold, molybdenum, platinum, and tungsten, which are less attractive from the standpoint of fabricability, showed even greater resistance to corrosion.

\section{Darex Technology}

Based on the laboratory-type investigations reported herein, it appears that several materials of construction would prove feasible from the standpoint of corrosion for the Darex dissolver unit. These, in order of merit, are titanium (75A) with a corrosion rate of less than 0.1 mil per month, Haynes 21 with less than 0.5 mil per month, and Type S-816 with less than 1 mil per month.

The studies have shown possible operating problems in the process from scale formation and from charges going passive.

The stripping columns and rectifier could be made from either tantalum or titanium, provided proper oxidizing conditions are maintained at the titanium surfaces.

\section{REFERENCE}

(1) Savolainen, J. E., and Blanco, R. E., Chem. Eng. Prog., 53, 78 to $81-$ F (February, 1957).

PDM:CLP:ELW:FWF/dc 